\title{
scumstan

\section{Numerical Simulation of Foundation Pit Dewatering Using Horizontal Seepage Reducing Body}

Jianxiu Wang ( $\nabla$ wang_jianxiu@163.com )

Tongji University

Yanxia Long

Tongji University

Yu Zhao

Tongji University

Weiqiang Pan

Shanghai Tunnel Engineering Company Co.,Ltd

Jianxun Qu

Shanghai Tunnel Engineering Company Co.,Ltd

Hanmei Wang

Shanghai Institute of Geological Survey

Yujin Shi

Shanghai Institute of Geological Survey

Xiaotian Liu

Tongji University

\section{Research Article}

Keywords: confined aquifer, foundation pit dewatering, vertical curtain, horizontal seepage reducing body (HSRB), three-dimensional numerical simulation, seepage mode

Posted Date: September 29th, 2021

DOI: https://doi.org/10.21203/rs.3.rs-936569/v1

License: (c) This work is licensed under a Creative Commons Attribution 4.0 International License.

Read Full License

Version of Record: A version of this preprint was published at Scientific Reports on January 26th, 2022. See the published version at https://doi.org/10.1038/s41598-022-05348-y. 


\section{(5)}

\section{Numerical simulation of foundation pit dewatering using horizontal seepage reducing body}

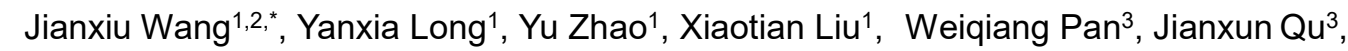

Hanmei Wang ${ }^{4}$, Yujin Shi ${ }^{4}$

${ }^{1}$ College of Civil Engineering, Tongji University, Shanghai, 200092, China

${ }^{2}$ Key Laboratory of Geotechnical and Underground Engineering of Ministry of Education, Tongji

University, Shanghai, China

${ }^{3}$ Shanghai Tunnel Engineering Company Co.,Ltd., Shanghai 200082, China

${ }^{4}$ Shanghai Institute of Geological Survey, Shanghai 200093, China

Corresponding author: *Jianxiu Wang, Department of Geotechnical Engineering, Tongji University, Shanghai 200092, China; wang_jianxiu@163.com; Tel: +86-13916185056,

+8621 65983036; Fax: +8621659851011

(1) 7 8 9 0 1 22 
Abstract: Groundwater level has to be lowered during deep excavation. A vertical curtain is usually adopted to control the drawdown both inside and outside a foundation pit in a built-up area. However, the cost and working difficulty increases substantially with the increasing depth of vertical curtains. In the manuscript, a kind of man-made horizontal seepage reducing body (HSRB) was introduced to shorten the vertical curtain depth and control drawdown. With the No. 4 shaft foundation pit of Guangyuan Project, Shanghai as background, HSRB was proposed in foundation pit dewatering. Microbially induced carbonate precipitation grouting technology was recommended to form an environment-friendly HSRB. Numerical method was used to simulate and understand the influence of position, thickness, and hydraulic conductivity of HSRB on groundwater level. The non-separated HSRB was better than the separate HSRB. Decreasing HSRB hydraulic conductivity was better than increasing HSRB depth. Four seepage modes are summarized considering vertical curtain penetration conditions into multi-aquifer, and the fifth seepage mode was formed for vertical curtain using man-made HSRB, which can be referred by similar engineering.

Keywords: confined aquifer, foundation pit dewatering, vertical curtain, horizontal seepage reducing body (HSRB), three-dimensional numerical simulation, seepage mode (3) 0 1 2 43 44 


\section{Introduction}

Coastal cities are often developed in economic because of convenient transportation. Urbanization develops quickly. Underground space is developed to serve the development of the city. In the aspect of engineering geology, engineering hydro-geology is important for a coastal city. Multi aquifer and multi aquitard are often encountered during underground exploitation. How to deal with the multiaquifer is significant for a deep excavation. Meanwhile, how to control the environment influence of lowering ground water level is also important. The excavation depth continuously increased under the urbanization demand, the required drawdown is increasing correspondingly. The contradiction between the increasing drawdown and strict requirements of surrounding land subsidence, together with groundwater resource protection, is also expanding. The majority of the accidents in foundation pit are concerned with groundwater. How to control groundwater level effectively during excavation has become a research hotspot (Cong et al., 2009; Wang et al., 2010; You et al., 2017; Cui, 2017;

Estanislao et al., 2017; Zhang et al., 2019; Li et al., 2021). The improper control of groundwater in excavation and construction processes often leads to large ground deformation (Caldhead et al., 2011; Xu et al., 2012; Pujes et al., 2017), damage to surrounding buildings (Song et al., 2014; Tan et al., 2018), quicksand and gushing (Zheng et al., 2016; Wu et al, 2018, 2019), and other engineering hazards. Field monitoring has indicated that the pumping and depressurization of confined water are the main factors causing ground settlement in foundation pit engineering $(\mathbf{C h e n}$ et al., 2009; Ye et al., 2009). The influence range reaches 10 to 15 times of the excavation depth (Gong et al., 2008). Therefore, groundwater control in excavation is necessary to ensure the safety both for foundation pit and environment.

At present, curtain cutoff, pumping, and recharging are widely used in groundwater control of a 
foundation pit (Fig. 1). Pumping is generally used and curtain is currently utilized to achieve foundation pit dewatering (Ha et al., 2018; Wang et al., 2016, 2017). Vertical curtain is usually used to cut off aquifers, decrease aquifer discharge section, change seepage direction, prolong seepage path. Some studies have evaluated the dewatering effect of the insertion depth of vertical curtain (Feng et al., 2013; Zhao et al., 2020; Li et al., 2017; Wu et al., 2019), pumping rate (Li et al., 2020), hydraulic conductivity, and distance between pumping well and vertical curtain (Wang et al., 2016, 2017). Wang et al. (2010) analyzed the mode and mechanism of the wall-well interaction, four patterns including fully enclosed, flush, partially enclosed, and fully exposed types are defined. The depth of vertical curtain penetrating into aquifer influence drawdown obviously. The interaction between vertical curtain and pumping well should be considered in foundation pit dewatering (i.e., wall-well interaction) (Wu et al., 2019). The application of the wall-well interaction in different projects was also summarized (Wang et al., 2009, 2010, 2013, 2014). However, the verticality of curtain, such as diaphragm wall, is difficult to be controlled precisely when the depth of vertical curtain is too large. If the verticality is not controlled in a certain value, the foot of two adjacent diaphragm wall splits leading to water leakage, which is dangerous for groundwater control. The vertical curtain cannot cut off aquifers and cannot meet the strict settlement control requirements of the surrounding environment when the aquifer is too deep. This type of deep confined aquifers has led to the use of horizontal curtain (Liu, 2010). However, horizontal curtain cannot avoid local leakage owing to complex hydrogeological conditions and construction quality. Local leakage points result in water inrush.

In the manuscript, a kind of man-made horizontal aquiclude with lower permeability was introduced in the dewatering system with vertical curtain. A kind of man-made horizontal seepage reducing 
body (HSRB) was proposed. With the No. 4 shaft foundation pit of the Guangyuan Project, Shanghai as background, HSRB was suggested to combine with vertical curtain to control groundwater drawdown. Microbially induced carbonate precipitation (MICP) grouting technology was suggested to form the HSRB. Finite difference method (FDM) was used to simulate the working mechanism of HSRB. The position, thickness, and hydraulic conductivity of HSRB were analyzed, which can be referred by similar projects.

\section{Material and methods}

\subsection{Project overview}

The No. 4 shaft foundation pit (Fig. 2) of Guangyuan Project in Pudong New District, Shanghai is located on Jihui Road of Gaoyan Institute, $97.1 \mathrm{~m}$ away from the West $220 \mathrm{kV}$ high-voltage iron tower, $12 \mathrm{~m}$ away from the east substation, and $8.5 \mathrm{~m}$ nearest to a two-story pump house. The surrounding environment of the shaft was complicated. The foundation pit is a $55 \mathrm{~m} \times 50 \mathrm{~m}$ rectangular in plane. The designed ground elevation is $4.5 \mathrm{~m}$, while the pit excavation depth is 39.6 $\mathrm{m}$. The foundation pit bottom was located in the silty clay of layer (5). The enclosure retaining system composed of diaphragm wall, outer trench cutting re-mixing deep wall (TRD), and inner support. Diaphragm wall was also used as vertical curtain for dewatering.

The 150-m depth layers of the site was composed of the Quaternary Holocene to Middle Pleistocene sedimentary strata. The strata are divided into 10 main engineering geological layers (Fig. 2(b)). The layer (5) 1 and above layers were generalized as shallow soil layers.

The aquifers consisted of phreatic aquifer (shallow soil layers), micro confined aquifer (layer (5), confined aquifer I (layer (7), confined aquifer II (layer (9)), and confined aquifer III (layer (11)) . The recommended hydraulic conductivity for each layer based on laboratory and in-site pumping 
test are shown in Table $\mathbf{1}$.

The foundation pit bottom was mainly located in clayey soil. Dewatering schemes for each aquifer under the pit were arranged as shown in Table 2.

An MICP man-made HSRB was suggested besides the vertical curtain consisted by diaphragm wall and TRD to reduce the influence on surrounding environment. MICP grouting technology was suggested to form the HSRB using bacillus pasteurella and cementing fluid $\left(\mathrm{CaCl}_{2}\right.$ solution, urea solution).

\subsection{Numerical modeling}

The hydrogeological conceptual model was translated into a mathematical model. The accuracy of the model was verified via model identification and verification. A three-dimensional unsteady flow continuity equation was established in anisotropic porous media:

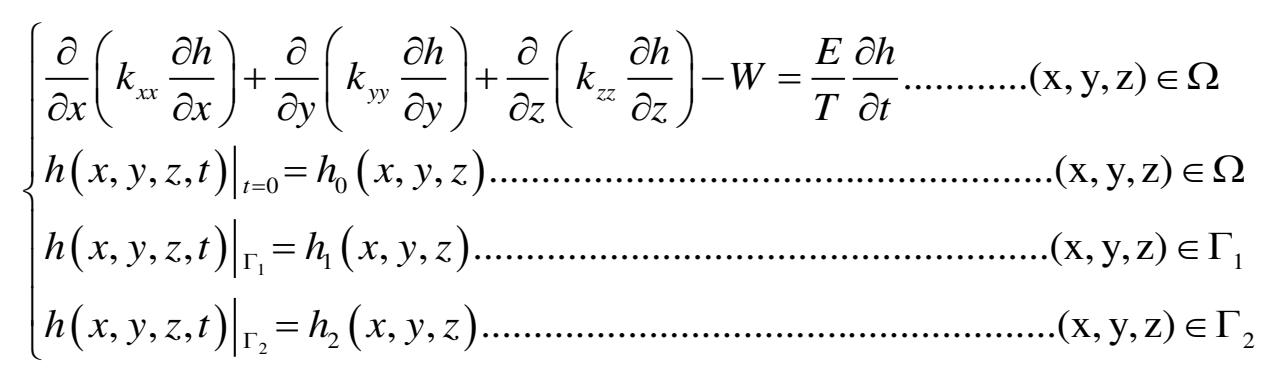

where $E=\left\{\begin{array}{ll}S & \text { Confined aquifer } \\ S_{y} & \text { Diving aquifer }\end{array} ; T=\left\{\begin{array}{ll}M & \text { Confined aquifer } \\ B & \text { Diving aquifer }\end{array} ; S_{s}=\frac{S}{M} ; S\right.\right.$ is water storage coefficient, $S_{y}$ is water supply, $S_{s}$ is water storage rate $(1 / \mathrm{m}) ; M$ is unit thickness of the confined aquifer $(\mathrm{m}) ; B$ is saturated thickness of groundwater in the phreatic aquifer unit body $(\mathrm{m}) ; k_{x x}, k_{y y}, k_{z z}$ are the anisotropic principal direction hydraulic conductivities $(\mathrm{m} / \mathrm{d}) ; h$ is head value of point $(x, y, z)$ at time $\mathrm{t}(\mathrm{m}) ; W$ is source and exchange items $(1 / \mathrm{d}) ; h_{0}$ is initial head value of the calculation domain $(\mathrm{m}) ; h_{1}$ is value of the water head around the first boundary $(\mathrm{m}) ; h_{2}$ is water head value of the first boundary of the foundation pit $(\mathrm{m}) ; t$ is time 
131 With the shaft foundation pit as center, a $2000 \mathrm{~m} \times 2000 \mathrm{~m}$ and $150 \mathrm{~m}$ deep modeling range was selected. The range was generalized into a 3D heterogeneous, horizontally isotropic, and unstable groundwater seepage system. The model was divided into 11 layers according to soil layer distribution. The ground elevation was taken as $+4.5 \mathrm{~m}$ (Fig. 3). The outer boundary was defined as constant water head boundary, and the bottom was set as impermeable boundary. Model hierarchy and its parameters are shown in Table $\mathbf{1 .}$

For the shaft foundation pit was too deep, the confined aquifer II which was seldom concerned previously had to be lowered. Although double vertical curtains were adopted, the layer (9) was not cut off. MICP HSRB was suggested to control the drawdown which was discussed in another manuscript*. According to laboratory results, the hydraulic conductivity of the layer (9) was decreased from $2.1 \times 10^{-3} \mathrm{~cm} / \mathrm{s}$ to $1.9 \times 10^{-4} \mathrm{~cm} / \mathrm{s}$ using the MICP technology.

In working conditions, the influence of the position, thickness, and permeability of the horizontal curtain on the foundation pit dewatering was designed. The working conditions of numerical simulation is shown in Table 3.

FDM was used to solve the problem. The conjugate gradient method (PCG) was chosen to simultaneously solve the algebraic equations. Groundwater level changes inside and outside the foundation pit were simulated.

\section{Results}

\subsection{Results without HSRB}

150 In case 1, four wells were used to pump water simultaneously, and the pumping rate of the four wells was $2950 \mathrm{~m}^{3} / \mathrm{d}$. After continuous pumping for 6 days, the dynamic water level of the fourth 
pumping well in layer $88_{22}$ of the pit decreased by $9.0 \mathrm{~m}$, and the minimum drawdown in the foundation pit was $5.56 \mathrm{~m}$, which met the requirements of the foundation pit anti-gushing calculation, and the drawdown in the layer $8{ }_{22}$ was $5.5 \mathrm{~m}$ (Fig. 4(a)). The change of the minimum water level decrease with time in the pit is shown in Fig. 5. At this time, water level in the range of $600 \mathrm{~m}$ of layer $88_{22}$ outside the pit decreased by $4.70 \mathrm{~m}$ to $0.83 \mathrm{~m}$. When the dewatering of layer (8) 22 met the drawdown requirement (i.e., continuous pumping for 6 days), the drawdown of four wells in layer (9) in the pit was $12.0 \mathrm{~m}$, and the minimum water level drawdown of layer (9) in the pit was $5.3 \mathrm{~m}$, which met the requirement of $2.3 \mathrm{~m}$ drawdown of layer (9) in the foundation pit antigushing calculation (Fig. 4(b)). The variation of the minimum water level drawdown with time in the pit is shown in Fig. 5(a). At this time, the water level within $600 \mathrm{~m}$ of layer (9) outside the pit decreased by $4.70 \mathrm{~m}$ to $0.82 \mathrm{~m}$, as shown in Fig.5(b).

As shown in Fig. 5, under the simultaneous action of four pumping wells, the water level of the deep foundation pit of the No. 4 working well decreased rapidly in the first day, reaching $5.3 \mathrm{~m}$. However, the design drawdown meeting the anti-gushing calculation can be achieved on the sixth day owing to the large permeability of the second confined aquifer in Shanghai and the large pumping rate of the foundation pit. As shown in Fig. 6, the drawdown of the water level outside the foundation pit of layer (8) 22 and layer (9) coincided with the distance, and the change of the drawdown curve can be divided into three areas. (1) Within the range of 0 to $150 \mathrm{~m}$, the drawdown gradient with the distance was large, and the change of water level was large. (2) Within the range of $150 \mathrm{~m}$ to $300 \mathrm{~m}$, the gradient of the drawdown with the distance began to decrease, and the change of water level was slow and gradually transited to the slow area. Beyond the range of $300 \mathrm{~m}$, the drawdown gradient with distance was small, and the change of water level was small as well. 


\subsection{Influence of HSRB position on dewatering}

Before forming a horizontal curtain by using the MICP technology, the depth of the horizontal curtain setting should be determined. This set the top plate of the horizontal curtain at the equilibrium position of the water and soil pressure after the excavation of the foundation pit. The calculation formula is as follows:

$$
\sum \gamma_{i} h_{i} \geq \gamma_{s} \gamma_{w} H
$$

where $\gamma_{i}$ is weight of each layer of soil $\left(\mathrm{kN} / \mathrm{m}^{3}\right) ; \quad h_{i}$ is thickness of each layer $(\mathrm{m}) ; \quad H$ is pressure head height at the horizontal curtain (m); $\gamma_{w}$ is water severity $\left(\mathrm{kN} / \mathrm{m}^{3}\right)$, take $10 \mathrm{kN} / \mathrm{m}^{3}$; and $\gamma_{s}$ is safety coefficient, take 1.05 .

The buried depth of the horizontal curtain was $82 \mathrm{~m}$, as calculated using formula (2).

According to the calculation results of working conditions 2 to 7, combined with the comparative analysis of the calculation results of condition 1, the influence of HSRB at different positions on deep foundation pit dewatering was studied. The thickness of HSRB was $4 \mathrm{~m}$, and the hydraulic conductivity was $5 \times 10^{-3} \mathrm{~cm} / \mathrm{s}$. According to the different positions of the horizontal curtain, the combination forms of the three-dimensional curtain were classified into inner-wrapping, flush, and separated types, as shown in Table 4.

Four pumping wells (i.e., 4y9-1 to 4y9-4) were used to pump water simultaneously in conditions 2 to 7 , and the pumping rate of the four wells was $2950 \mathrm{~m}^{3} / \mathrm{d}$. According to the calculation results, the time required for the drawdown of the water level in the pit to reach the design drawdown can be obtained, as shown in Fig. 7. When the buried depths of HSRB were 80, 82, 84, and $86 \mathrm{~m}$. That is, when the horizontal curtain was not separated from the three-dimensional curtain, the time required to reach the water level in the pit to reach the designed drawdown level of the foundation pit anti- 
gushing calculation was substantially shortened compared with that without horizontal curtain, which was only approximately $28.8 \mathrm{~min}$, and only $0.4 \%$ of that without horizontal curtain. For several working conditions of the non-separated three-dimensional curtain, the position and depth of horizontal curtain had minimal influence on the dewatering time of the deep foundation pit.

When the buried depths of the horizontal curtain were 88, 90, and $92 \mathrm{~m}$ (i.e., HSRB and vertical curtain were separated and combined to form separate three-dimensional curtain), the times required to reach the design drawdown were $0.35,0.55$, and $0.8 \mathrm{~d}$, respectively. Compared with the nonseparated three-dimensional curtain, the time to reach the design drawdown was increased. However, the time to reach the design drawdown was also significantly shorter than that without HSRB, which was only approximately $10 \%$ of that without HSRB. With the deepening of the buried depth of the horizontal curtain, the time required for the foundation pit dewatering to reach the design drawdown increased correspondingly.

Therefore, from the perspective of dewatering time, the effect of setting HSRB on the design drawdown of the foundation pit dewatering was significant, and the effect of the non-separation three-dimensional curtain was better than that of the separation three-dimensional curtain. The work efficiency of setting horizontal curtain was evidently higher than that without HSRB. In practical engineering, the construction period was substantially reduced, construction efficiency was considerably improved, construction nodes can be completed in advance, and good social and economic benefits will be achieved.

To significantly compare the influence of the different types of three-dimensional curtain on deep foundation pit dewatering, the non-separation and separation three-dimensional curtain were studied separately. Working conditions 2 to 4 were calculated to study the influence of the position of the 
non-separating horizontal curtain on the three-dimensional curtain-well group system. The minimum drawdown of the water levels in the pit of layers (8) 22 and (9) are shown in Figs. 7(a) and 7(b), respectively. The drawdown time curve under the working conditions of 82, 84, and $86 \mathrm{~m}$ of the horizontal curtain had minimal difference. After $28.8 \mathrm{~min}$ of pumping well operation, the drawdown of the water level in the pit reached $5.6 \mathrm{~m}$ of the design requirement.

Working conditions 4 to 6 were calculated to study the influence of the position of the separated horizontal curtain on the three-dimensional curtain-well group system, working conditions 4 to 6 were calculated. The minimum drawdown of the water levels in the pit of layers (8) 22 and (9) are shown in Figs. 7(c) and 7(d), respectively. The time required to reach the design drawdown in the pit increased with the deepening of HSRB. Before reaching the design drawdown, the deeper HSRB was buried, the smaller the minimum drawdown in the foundation pit under the corresponding working conditions.

During the excavation of the deep foundation pit in Shanghai, the main purpose of extracting groundwater from the deep second confined aquifer was to reduce the water head pressure at the bottom of the pit and avoid the occurrence of sudden gushing at the bottom of the pit. However, the decrease of the groundwater level leads to an increase of the effective self-weight stress of the layer below the original water level, soil consolidation, ground settlement around the foundation pit, and foundation pit dewatering on the surrounding environment. The setting of vertical curtain relatively reduced the impact of foundation pit dewatering on the surrounding environment. However, merely 
the surrounding environment. Hence, HSRB should be added to further eliminate the settlement of the pit bottom caused by foundation pit dewatering. Therefore, the influence of HSRB on groundwater level outside the pit must also be referred to evaluate the effect of the different HSRB position, thickness, and hydraulic conductivity on the three-dimensional curtain-well group system on the deep foundation pit dewatering engineering.

As shown in Figs. 8(a) and 8(b), the variation law of the drawdown distance curve outside the pit of layers (8) 22 and(9) under each working condition was consistent. Meanwhile, the drawdown value and drawdown trend of the water levels outside the pit of layers (8) 22 and (9) were basically the same. Therefore, this study only analyzed the drawdown variation outside the pit of layer $88_{22}$ with distance. For the working condition of non-separated three-dimensional curtain, when the HSRB buried depths were 82,84 , and $86 \mathrm{~m}$, the drawdown distance curves of the three working conditions were nearly coincidental. When the drawdown of water level in the pit reached the design requirement of $5.52 \mathrm{~m}$, the maximum drawdown of the water level outside the pit was $2.4 \mathrm{~m}$, and the drawdown of the water level outside the pit was $0.5 \mathrm{~m}$ when the drawdown of the water level outside the pit was $150 \mathrm{~m}$. For the non-separated three-dimensional curtain, the position of the HSRB dewatering project, which can be disregarded.

For the working conditions of the separated curtain (i.e. when HSRB buried depths were 88,90 , and $92 \mathrm{~m}$ ), the variation trend of the drawdown distance curve outside the pit under the three working conditions was consistent, and the curve slope was the same. That is, the drawdown rate of the water level outside the pit was the same with a decrease in distance. However, the drawdown of the water level outside the pit was different with the varying positions of HSRB. The deeper the HSRB was 
buried, the higher the drawdown of the water level outside the pit; and the greater the settlement of the ground outside the pit, the greater the impact on the environment. When HSRB depth was $88 \mathrm{~m}$, the maximum drawdown of the water level outside the pit was $4.3 \mathrm{~m}$ and the maximum drawdown $400 \mathrm{~m}$ away from the pit was $0.84 \mathrm{~m}$. When HSRB depth was $90 \mathrm{~m}$, the maximum drawdown of the water level outside the pit was $4.5 \mathrm{~m}$ and the maximum drawdown $450 \mathrm{~m}$ away from the pit was $0.91 \mathrm{~m}$. When the HSRB depth was $92 \mathrm{~m}$, the maximum drawdown of the water level outside the pit was $4.6 \mathrm{~m}$ and the maximum drawdown $500 \mathrm{~m}$ away from the pit was $0.92 \mathrm{~m}$. In summary, for the non-separation type of three-dimensional curtain, the effects of the innerwrapped, flush, and transitional three-dimensional curtains on the deep foundation pit dewatering engineering are equivalent, and they are better than the effect of the separation type threedimensional curtain. In the separated three-dimensional curtain, the closer the horizontal curtain to the bottom of the vertical curtain, the better the effect. Therefore, the design form of non-separated three-dimensional curtain should be adopted in practical engineering.

\subsection{Influence of HSRB thickness on dewatering}

From the analysis results of the influence of HSRB position on the three-dimensional curtain-well group system, the effect of the non-separated HSRB was better than the separated horizontal curtain, and the influence of the HSRB position on the dewatering effect of the internal three-dimensional curtain was minimally evident. Given that the MICP technology was used to form a horizontal curtain, which involved the seepage of bacteria and cementation liquids in groundwater, to avoid the impact of bacteria and cementation liquids used in MICP on the surrounding environment, vertical curtain was used to control the MICP bacteria and cementation liquids within the scope of the vertical curtain of foundation pit. Therefore, when the buried depth of the horizontal curtain roof 
was set at $82 \mathrm{~m}$, the thickness of the MICP bacterial liquid infusion was not over $6 \mathrm{~m}$, thereby reducing the impact on the surrounding environment.

If the pumping rate of $2950 \mathrm{~m}^{3} / \mathrm{d}$ was the same as that of conditions 2 to 7 , and the horizontal curtain thickness was increased, then dewatering in the foundation pit rapidly reached the designed drawdown. Difficulty is encountered in analyzing the relationship between the drawdown of HSRB with different thickness and time. Therefore, the pumping rate of the pumping well should be reasonably reduced. Designing conditions 8, 9, and 2 were compared and analyzed to evaluate the influence of pumping rate of the pumping well on the dewatering of the deep foundation pit. Only the pumping rate was different under the three conditions, and other conditions were the same. The specific parameters are shown in Table 5.

According to the numerical simulation results, the drawdown-to-time curves of the water level in the pit under three conditions of the different pumping rates are shown in Figs. 9(a) and Fig. 9(b), and the drawdown to distance curves outside the pit are shown in Figs. 10(a) and 10(b). As shown in Figs. 9(a) and 9(b), when the pumping rate of the pumping well decreased from $2950 \mathrm{~m}^{3} / \mathrm{d}^{\text {to }}$ $2500 \mathrm{~m}^{3} / \mathrm{d}$, the time required for the water level in the pit to reach the design drawdown increased. $\mathrm{m}^{3} / \mathrm{d}, 72$ min was needed to reach the design drawdown.

As shown in Figs. 10(a) and 10(b), the drawdown value and drawdown trend of the water level 
the water level outside the pit of the two layers with the distance were analyzed. When pumping rate was $2950 \mathrm{~m}^{3} / \mathrm{d}$, the maximum drawdown was $2.3 \mathrm{~m}$, reaching a stable drawdown of $0.48 \mathrm{~m}$ at $200 \mathrm{~m}$ away from the pit. When pumping rate was $2500 \mathrm{~m}^{3} / \mathrm{d}$, the maximum drawdown was $2.5 \mathrm{~m}$, reaching a stable drawdown of $0.52 \mathrm{~m}$ at $200 \mathrm{~m}$ away from the pit. When pumping rate was 2000 $\mathrm{m}^{3} / \mathrm{d}$, the maximum drawdown was $3.1 \mathrm{~m}$, reaching a stable drawdown of $0.75 \mathrm{~m}$ at $300 \mathrm{~m}$ away from the pit. With a decrease in pumping rate, the maximum drawdown of the water level outside the pit increased, and the distance to reach the stable drawdown level also increased. That is, the impact on the surrounding environment increased substantially. In summary, different pumping rates have an impact on the effect of deep foundation pit dewatering. The lower the pumping rate, the longer the time to reach the designed drawdown level and the larger the drawdown and influence range of the water level outside the pit. Therefore, a high pumping rate was beneficial to the deep foundation pit dewatering project, although a necessary action is to set a reasonable pumping rate that considers the actual situation of the construction site.

To study the influence of HSRB thickness on the three-dimensional curtain-well group system, the curtain roof was $82 \mathrm{~m}$, and the horizontal curtain thicknesses in each working condition were 3, 4, parameters are shown in Table 6.

According to the numerical simulation results, the drawdown time curves of the water level in the

5 , and $6 \mathrm{~m}$. The three-dimensional curtain formed by the horizontal and vertical curtains was innerwrapped three-dimensional curtain, and the hydraulic conductivity was $5 \times 10^{-3} \mathrm{~cm} / \mathrm{s}$. The specific pit under four working conditions with different thicknesses of the HSRB are shown in Figs. 11(a) 
and 11(b). Evidently, the variation law of the drawdown time curve in the two soil layers was consistent. With the increase of the HSRB thickness, minimal time was needed to achieve the design drawdown. Before reaching the design drawdown, the greater the thickness of HSRB, the greater the drawdown of the water level in the foundation pit. When water level in the pit reached the designed drawdown in layer 822, drawdown in the pit in layer (9) can reach at least $5.4 \mathrm{~m}$, which can meet the design drawdown of the anti-gushing calculation in layer (9). Therefore, the pumping time only needed to meet the drawdown requirements of the water level in layer 8 22 . In case 8 , when HSRB thickness was $3 \mathrm{~m}$ and the drawdown in the pit met the design requirements, the pumping well should work for approximately $0.15 \mathrm{~d}$. In case 9, when HSRB thickness was $4 \mathrm{~m}$ and the drawdown in the pit met the design requirements, the pumping well should work approximately $72 \mathrm{~min}$. When the horizontal curtain thickness was $5 \mathrm{~m}$ in working condition 10 and drawdown in the pit met the design requirements, the pumping well must work for approximately 36 min. When HSRB thickness of working condition 11 was $6 \mathrm{~m}$ and drawdown in the pit met the design requirements, the pumping well should work for approximately $22 \mathrm{~min}$. When HSRB thickness was $3 \mathrm{~m}$ to $6 \mathrm{~m}$, pumping time for the foundation pit dewatering to reach the design water level was reduced by approximately $50 \%$ when the thickness was increased by $1 \mathrm{~m}$. Accordingly, the pumping efficiency approximately doubled.

The thicker the HSRB, the higher the working efficiency of the pumping well. However, with the increase of thickness, the improvement range of the working efficiency of the pumping well decreased. Therefore, designing a three-dimensional curtain in an actual project entails comprehensive consideration of the effect and cost should be comprehensively considered to select the most appropriate horizontal thickness. 
According to the numerical simulation results, the drawdown-distance curves of the four working conditions with different HSRB thicknesses are shown in Figs. 12(a) and 12(b). The drawdown value and trend of the drawdown rate of water level outside the pit were the same with layers (8) 22 and(9). Evidently, this study only analyzed the drawdown variation of the water level outside the pit with the distance in layer 8 22 . The thicker the HSRB, the deeper the water level decreased at the same distance outside the pit. The change trend of the drawdown-distance curve was consistent under the four conditions, and the slope of the curve was the same. That is, the drawdown rate with distance was the same. When HSRB thickness was $3 \mathrm{~m}$, the maximum drawdown outside the pit was $3.1 \mathrm{~m}$, reaching a stable drawdown of $0.6 \mathrm{~m}$ at $350 \mathrm{~m}$ away from the pit. When HSRB thickness was $4 \mathrm{~m}$, the maximum drawdown outside the pit was $2.5 \mathrm{~m}$, reaching a stable drawdown of $0.52 \mathrm{~m}$ at $250 \mathrm{~m}$ away from the pit. When HSRB thickness was $5 \mathrm{~m}$, the maximum drawdown outside the pit was $2.0 \mathrm{~m}$, reaching a stable drawdown of $0.53 \mathrm{~m}$ at $200 \mathrm{~m}$ away from the pit. When HSRB thickness was $6 \mathrm{~m}$, the maximum drawdown outside the pit was $1.7 \mathrm{~m}$, and the stable drawdown was $0.51 \mathrm{~m}$ at $200 \mathrm{~m}$ away from the pit. When HSRB thickness increases from $3 \mathrm{~m}$ to $4 \mathrm{~m}$, the lifting effect was significant. Thereafter, with the increase of thickness, the curves begin to get closer with the increase of thickness, and a trend of gradual coincidence was observed. That is, when the horizontal curtain thickness relatively increased, increasing the horizontal curtain thickness will no longer significantly improve the foundation pit dewatering effect.

Therefore, with an increase in HSRB thickness, the time required for the drawdown in the pit to reach the design value was reduced, the maximum drawdown outside the pit was reduced, and the influence range of drawdown outside the pit was reduced. When HSRB thickness was small, the effect of increasing curtain thickness was considerably evident. When thickness increased to a 
certain extent, the effect of increasing curtain thickness was minimally evident. Therefore, the effect and cost should be comprehensively considered in the engineering design of three-dimensional curtain, and the most appropriate horizontal curtain thickness must be selected.

\subsection{Influence of HSRB hydraulic conductivity on dewatering}

According to the analysis results of the influence of the position and thickness of the horizontal seepage reducing curtain on the dewatering effect of the deep foundation pit of the threedimensional curtain-well group system, on the basis of the existing 86-m deep vertical curtain, adding an HSRB with the roof buried depth of $82 \mathrm{~m}$ and thickness of $6 \mathrm{~m}$ had the best effect on the control of dewatering period and the decline of the underground water level outside the pit in the dewatering process of the deep foundation pit.

Working conditions 13 to 15 and 12 were compared and analyzed to study the influence of hydraulic conductivity of HSRB on deep foundation pit dewatering. Four pumping wells under four working conditions were pumped at a pumping rate of $2500 \mathrm{~m}^{3} / \mathrm{d}$, the buried depth of HSRB roof was $82 \mathrm{~m}$, and HSRB thickness was $6 \mathrm{~m}$. The form of the three-dimensional curtain formed by horizontal and vertical curtains was inner-wrapped three-dimensional curtain. The hydraulic conductivities of working conditions $13,12,14$, and 15 were $1 \times 10^{-2}, 5 \times 10^{-3}, 1 \times 10^{-4}$, and $5 \times 10^{-4} \mathrm{~cm} / \mathrm{s}$, respectively, as shown in Table 7.

According to the results of the numerical simulation, drawdown-time curves of the water level in the pit under four conditions with different hydraulic conductivities are shown in Figs. 13(a) and 13(b), and the drawdown to distance curves outside the pit are shown in Figs. 14(a) and 14(b). As shown in Figs. 13(a) and Fig. 13(b), with a decrease in the hydraulic conductivity of the HSRB, the time required for the water level in the pit to reach the design drawdown decreased. When water 
level in the pit reached the designed drawdown of layer $8{ }_{22}$, the drawdown of the water level in the pit of layer (9) can reach at least $5.5 \mathrm{~m}$, which met the design drawdown of the surge calculation of layer (9). Therefore, the pumping time only needed to meet the seepage reduction demand of layer 88 22 . When the hydraulic conductivity of HSRB was $1 \times 10^{-2} \mathrm{~cm} / \mathrm{s}, 0.20 \mathrm{~d}$ was needed to reach the design drawdown. When the hydraulic conductivity of HSRB was $5 \times 10^{-3} \mathrm{~cm} / \mathrm{s}, 22 \mathrm{~min}$ was needed to reach the design drawdown. When the hydraulic conductivity of HSRB was $1 \times 10^{-3}$ $\mathrm{cm} / \mathrm{s}$, the water level in the foundation pit decreased rapidly, reaching $9.3 \mathrm{~m}$ in $15 \mathrm{~min}$. When the hydraulic conductivity of HSRB was $5 \times 10^{-4} \mathrm{~cm} / \mathrm{s}$, the drawdown of water level in the foundation pit was faster than that in working condition 14, reaching $11.1 \mathrm{~m}$ in $15 \mathrm{~min}$. When the hydraulic conductivity of HSRB was below $1 \times 10^{-3} \mathrm{~cm} / \mathrm{s}$, only $5 \%$ of the hydraulic conductivity of $1 \times 10^{-2}$ $\mathrm{cm} / \mathrm{s}$ was needed to reach deeper drawdown. Therefore, dewatering time can be considered a secondary factor, and drawdown outside the pit was mainly considered. That is, the impact of the foundation pit dewatering on the environment outside the pit.

As shown in Figs. 14(a) and (b), the drawdown value and drawdown trend outside the pit of the two layers were the same. With a decrease in the hydraulic conductivity of HSRB, the maximum drawdown of the water level outside the pit was smaller, and the influence of foundation pit dewatering on the outside of the pit became smaller. Therefore, only the variation of the drawdown of water level outside the pit of layer (8) 22 with the distance was analyzed. When the hydraulic conductivity of HSRB was $1 \times 10^{-2} \mathrm{~cm} / \mathrm{s}$, the maximum drawdown of the water level outside the pit was $3.2 \mathrm{~m}$, and stable drawdown of the water level was $0.67 \mathrm{~m}$ at $350 \mathrm{~m}$ away from the pit. When the hydraulic conductivity of HSRB was $5 \times 10^{-3} \mathrm{~cm} / \mathrm{s}$, the maximum drawdown of the water level outside the pit was $1.7 \mathrm{~m}$, and stable drawdown of the water level was $0.48 \mathrm{~m}$ at $150 \mathrm{~m}$ away from 
the pit. When the hydraulic conductivity of HSRB was $1 \times 10^{-3} \mathrm{~cm} / \mathrm{s}$, the maximum drawdown of the water level outside the pit was $0.93 \mathrm{~m}$, and stable drawdown of the water level was $0.42 \mathrm{~m}$ at $150 \mathrm{~m}$ away from the pit. When the hydraulic conductivity of HSRB was $5 \times 10^{-4} \mathrm{~cm} / \mathrm{s}$, the maximum drawdown of the water level outside the pit was $0.71 \mathrm{~m}$, and the stable drawdown of the water level was $0.42 \mathrm{~m}$ at $150 \mathrm{~m}$ away from the pit. With a decrease in hydraulic conductivity of horizontal curtain, the curves of each working condition were increasingly closer, particularly when the hydraulic conductivity of HSRB was below $1 \times 10^{-3} \mathrm{~cm} / \mathrm{s}$. Accordingly, the curves began to overlap, thereby indicating that the improvement effect of lowering the hydraulic conductivity when it was below $1 \times 10^{-3} \mathrm{~cm} / \mathrm{s}$ was no longer evident.

Therefore, with a decrease in the hydraulic conductivity of HSRB, the time required for water level in the pit to reach the design drawdown was reduced, the maximum drawdown outside the pit was technology to reduce the permeability of sand, blindly pursuing lower permeability is no longer necessary. In deep foundation pit dewatering, vertical curtains are often adopted in multi-aquifer and multi- 
seepage modes of foundation pit considering vertical penetration condition in MAMA. The seepage mode outside curtain during portal and export dewatering for a shield machine in MAMA was defined as the fourth seepage mode (Wu et al. 2010). The four seepage modes (Fig. 15) were based on vertical curtain and the penetration conditions of MAMA (Wu 2003; Wang et al. 2009; Xu et

\section{al. 2014; Wu et al. 2015a, f; Zhang et al. 2015b).}

(1) Mode I (Curtain penetrating shallow aquifers and partially penetrating bottom aquitard of the target aquifer of a MAMA)

In the mode, vertical curtain cuts off all the target aquifers (should be dewatered) of MAMA. The bottom of the vertical curtain penetrated all shallow aquifers and partially penetrated the top aquitard of the lowest confined aquifer that should be dewatered. The side and bottom boundaries of the water flow were the cutoff wall and aquitard, respectively. Water level in the pit was lowered using pumping wells within the boundaries. Three sub-modes were defined according to the dewatered aquifers.

Mode 1-1: The excavation face located in the phreatic aquifer and underlying confined water pressure satisfied anti-gushing conditions, and vacuum well point, waterway, and shallow pumping well were arranged to drain the aquifers.

Mode 1-2: The excavation face located in the phreatic aquifer and underlying confined water pressure did not satisfy anti-gushing conditions, and pumping wells were arranged to drain the phreatic aquifer and lower the water level of the confined aquifer.

Mode 1-3: The excavation face located in the confined aquifer, the top aquitard of the shallow confined aquifer was excavated, and pumping wells were arranged to drain the phreatic aquifer, shallow confined aquifers, and exposed confined aquifer. 
(2) Mode II (Curtain penetrating shallow aquifers and partially penetrating top aquitard of a MAMA).

The vertical curtain penetrated the top aquitard of the deepest confined aquifer that should be dewatered. Vertical curtain penetrated and cut off all shallow aquifers. However, no vertical curtain penetrated the deepest confined aquifer that needed to lower water level. Three sub-modes were defined according to the dewatered aquifer. Modes 2-1, 2-2, and 2-3 were the same as modes 1-1, 1-2, and 1-3 for shallow aquifers. Separated pumping wells had to be arranged in the deepest confined aquifer inside or outside the pit to lower the water level. Seepage mode included the water flow in shallow aquifers cut off by walls, underlying water flow in deep aquifer without cutoff walls, and cross-flow between the shallow and deep aquifers.

(3) Mode III (Curtain penetrating shallow aquifers and partially penetrating deep target aquifers of a MAMA).

The cut off wall penetrated the shallow MAMA aquifers and partially penetrated deep confined aquifer that should be dewatered. Cut off shallow aquifers can be divided into three sub-modes similar to those defined in Modes I and II. According to the depth of the cut off wall and pumping well filter tubes bottom, four pumping well arrangement patterns were formed for the underlying partially penetrated curtain, including the (1) entire filter tube enveloped by curtain pattern, (2) filter tube partially enveloped by curtain and part of the filter tube exposed a curtain pattern, and (3) all filter tube exposed curtain pattern. Nine seepage modes were combined: Mode III-1i(i=1,2,3), Mode III- $2 \mathrm{j}(\mathrm{j}=1,2,3)$, and Mode III-3k $(\mathrm{k}=1,2,3)$ in curtain pattern. Water flow occurred in cut off shallow aquifers and partially cut off deep aquifers, together with the leakage and crossflow between the shallow and deep aquifers. 
(4) Mode IV (Pumping outside curtain and nearby shield tunnel type).

When a shield machine entered or left the portal or expose working pit, dewatering was occasionally necessary to control water pressure and leakage of reinforced soil. Pumping wells were arranged outside the cut off wall and near the shield machine and tunnel. The cutoff wall and tunnel influenced the water flow as boundaries. The dewatering type was defined as Mode IV.

The current four seepage modes were used widely used. However, vertical curtain may be unable to effectively cut off all confined aquifers of MAMA and achieve the designed dewatering effects when the confined aquifer was considerably thick or buried substantially deep. The current study introduced a HSRB as man-made aquiclude to decrease hydraulic conductivity in deep confined aquifer. The man-made HSRB belongs to a type of anti-seepage body formed by various construction technologies at a certain depth of confined aquifers. Horizontal curtain was previously used as a complete impermeable curtain, the seepage of which belongs to Mode I. Horizontal curtain required advanced construction technology and cost was high. The man-made HSRB was formed to improve the vertical water blocking effect rather than a water proof curtain. HSRB reduced the hydraulic conductivity of aquifer soil by grouting and other techniques to weaken the hydraulic connection inside and outside the pit. The conceptual model is shown in Fig. 16.

HSRB decreased the hydraulic conductivity of the soil by grouting in confined aquifer, formed an HSRB with certain thickness to reduce seepage in foundation pit dewatering, increased hydraulic gradient in the curtain body, and reduced outlet water pressure and effectively controlled seepage flow. Compared with the complete impervious curtain, this method was economical, simple, and easy to realize. Seepage occurred inside the body and bears substantial hydrodynamic force to decrease the outlet water pressure. 
According to the relative position of HSRB and vertical curtain, the combination can be divided into two categories: separated and non-separated. Non-separated can be sub-divided into three types: inner-wrapped, transitional, and flush.

(1) Mode V-1(Separated): HSRB was separated from the suspension waterproof curtain, as shown in Fig. 17(a). HSRB was equivalent to setting a certain area as man-made aquiclude in the aquifer below the vertical curtain at certain depths. Mode was formed in the cases that the HSRB was deeper than vertical curtain and formed after the vertical one.

(2) Mode V-2 (Inner-wrapped curtain): The HSRB was inside the vertical curtain, as shown in Fig. 17(b), similar to a box that only allows a small amount of water to seep at the bottom. Given that HSRB was completely within the vertical curtain range, when grouting technology was used to form HSRB, vertical curtain can prevent grout from spreading into surrounding groundwater, thereby reducing environmental pollution.

(3) Mode V-3 (Flush curtain): The top of the HSRB connected with the vertical curtain, as shown in Fig. 17(c). This three-dimensional curtain was approximately the same as the inner-wrapped three-dimensional curtain, and both form a partially closed box with the vertical curtain. The construction of this type of scheme can avoid the influence of the vertical curtain and can be realized through some processes outside the pit. However, the influence of the groundwater seepage field outside the pit should be considered.

(4) Mode V-4 (Transitional curtain): Given that the horizontal body had a certain thickness, the top of the horizontal body was within the depth of the vertical curtain and the bottom plate was outside the range of the vertical curtain depth. This three-dimensional curtain that transitioned from an inner envelope to a level was defined as a transition three-dimensional curtain, as shown in Fig. 17(d). 
Suspended vertical curtain and HSRB were combined in foundation pit dewatering, as shown in Fig.

18. The HSRB was divided into full and local HSRB. Full HSRB contacted with vertical curtain to form a partially closed box. The partially HSRB did not contact vertical curtain to form a non-closed solid curtain.

When the survey data showed numerous underlying partial impermeable zones or weakly permeable water bodies in the confined aquifer, these natural horizontal water-tight structures can be utilized to control the design cost and construction difficulty (i.e., local horizontal curtains were set around the weak water-permeable body).

\subsection{HSRB construction method}

The man-made HSRB can be considered a type of permeable horizontal curtain. At present, the main forms of vertical curtain include diaphragm wall, soil mixing wall (SMW) method, cementsoil mixing method, and high-pressure jet grouting method. Diaphragm wall can be used as retaining structure, and widely used as vertical curtain in deep foundation pit. However, its cost was high when used as curtain. The SMW method can also combine the functions of waterproof and retaining structure by mixing cement slurry with the original soil and inserting an H-shaped steel. The SMW method had short construction period, low environmental impact, good seepage insulation effect, and relatively low cost. This method included dry and wet construction processes with short construction period and low requirements for construction conditions. However, the working depth of the method was limited. The high-pressure jet grouting method can combine support row piles or soil nail walls to achieve waterproof and retain functions. It cut the soil mass through the cement slurry ejected from the nozzle, mixing the undisturbed soil and slurry to form cement soil, and hydraulic conductivity of cement-soil was considerably lower than that of the undisturbed soil mass. 
This method was easy to construct and construction equipment was simple. However, guaranteeing construction quality was difficult when the construction depth was considerably deep. Freezing method has immense advantages in the construction of complex and special strata, including convenient construction and recoverable engineering equipment. The deeper the excavation depth, the better the freezing method. However, water cannot be pumped during the freezing period. Special attention should be given to the overall stability, freezing, and thermal insulation of the curtain.

The HSRB construction method should be selected according to engineering, geological, and economic conditions. The HSRB was permeable instead of impermeable curtain, the main purpose was to reduce the hydraulic conductivity of the target aquifer from 1 to 2 order of magnitude to decrease the permeability of the target aquifer. Grouting method was often suggested. However, the high pressure of jet cement destroyed the structure of aquifer and aquitard, and partial leakage cannot be avoided. When depth was large, the connection of the different piles was difficult. This study suggested the MICP grouting technology to form HSRB with grout of bacillus pasteurella and cementing fluid $\left(\mathrm{CaCl}_{2}\right.$ solution, urea solution), which has minimal impact on the environment. The structure of the aquitard and aquifer were not destroyed.

The traditional materials used in the traditional horizontal curtain forming method, such as cement and lime cementitious materials, caused adverse effects on the ecological environment of groundwater. Moreover, traditional grouting materials have difficulty entering the sand layer with small pores, such as layer (9) of fine sand in Shanghai. The original structure of the target aquifer was destroyed in traditional technology to form a horizontal curtain. Therefore, using the MICP grouting technology to form environment-friendly horizontal curtain can solve numerous limitations 

presented in another manuscript*

\section{Conclusions}

(1) On the bases of vertical waterproof curtain applied in foundation pit dewatering engineering,

HSRB was added to form a horizontal man-made aquiclude. The vertical curtain, HSRB and pumping wells were designed to work together. The combination included separated and nonseparated types.

(2) For non-separation HSRB, the inner-wrapped, flush, and transitional vertical curtains were equivalent. Non-separation HSRB, were better than the separation HSRB. For separated HSRB, the closer to the vertical curtain bottom, the better the dewatering effect.

(3) The time reaching the designed drawdown, the maximum outside drawdown, and influence range decreased with increasing HSRB thickness.

(4) When HSRB thickness was thin, increasing HSRB thickness was considerably evident. When HSRB thickness was increased to a certain extent, the increasing of curtain thickness was less evident. The effect and cost should be comprehensively considered, and the most appropriate HSRB thickness must be selected.

(5) Based on the combination of vertical curtain and HSRB, the fifth seepage mode was suggested for foundation pit dewatering which can be referred by similar projects. The authors declared that there is no conflict of interest. 
This study is sponsored by the Shanghai Municipal Science and Technology Project (18DZ1201301; 19DZ1200900), Key Laboratory of Land Subsidence Monitoring and Prevention, Ministry of Natural Resources of the People's Republic of China (No. KLLSMP202101), Suzhou Rail Transit Line 1 Co. Ltd, Xiamen Road and Bridge Group (XM2017-TZ0151; XM2017-TZ0117), China Railway 15 Bureau Group Co., and IGCP Project (663-La Subsidence in Coastal cities).

\section{References}

Calderhead, A.I., Therrien, R., Rivera, A., Martela, R., Garfiasd, J., 2011. Simulating pumpinginduced regional land subsidence with the use of InSAR and field data in the Toluca Valley, Mexico. Adv. Water Resour. 34, 83-97.

Cong, A.S, 2009. Discussion on seepage stability of deep foundation pit on multilayer foundation. Journal of rock mechanics and engineering, 28 (10): 2018-2023.

Cui, Y.G., 2017. Study on water head rise of bottom side surge of foundation pit with suspended curtain. Acta geologica Sinica, , 25 (3): 699-705.

Chen, H.S., Chen, B., He, D., 2009. Risk classification of ground settlement for deep foundation pit engineering in Shanghai. Journal of underground space and engineering, 5 (4): 829-833.

Estanislao, P., Ander, L., Jesus, C., et al., 2012. Barrier effect of underground structures on aquifers. Elsevier B.V, 145-146.

Feng, X.L., Li, D.G., 2013. Calculation of foundation pit leakage under the condition of falling bottom waterproof curtain. Hydrogeology and engineering geology , 40 (05): 16-21.

Gong, S.L., Ye, W.M., Chen, H.S., et al., 2008. Evaluation theory and method of ground settlement of deep foundation pit engineering in Shanghai. Chinese Journal of geological hazards and prevention, 19 (4): 55-60. 
Ha, D., Zhu, K.P., Li, Z., et al., 2018. Optimization of diaphragm wall depth under confined aquifer conditions in Tianjin. Journal of underground space and engineering, 14 (02): 490-499.

Li, F., Xu, J., Zhang, F., et al., 2017. Numerical simulation of uplift resistance in deep foundation pit excavation under seepage. Journal of underground space and engineering, 13 (04): 1088-1097. Li, G.M., Li, M.S., 2020. Study on dewatering control measures of foundation pit with suspended waterproof curtain. Journal of underground space and engineering, 16 (03): 921-932.

Li, Y., Chen, D., Liu, X.W., et al., 2021. Simplified calculation method for decompression and dewatering of deep foundation pit with suspended waterproof curtain. Geotechnical mechanics, (03): $1-8$

Liu, Z.Y., 2010. Study on dewatering scheme of deep foundation pit with deep and strong permeable layer for Kunming Metro. Railway Survey and design, (5): 266-270.

Ni, J.C., Cheng, W.C., Ge, L., 2013. A simple data reduction method for pumping tests with tidal, partial penetration, and storage effects. Soils Found. 53 (6), 894-902.

Pujades, E., De Simone, S., Carrera, J., Vázquez-Suñé, E., Jurado, A., 2017. Settlements around pumping wells: analysis of influential factors and a simple calculation procedure. J. Hydrol. 548, 225-236.

Song, J.X., Nie, X.H., Zhang, J.Y., 2014. Prediction technology of adjacent underground pipelines damage caused by excavations dewatering. Build. Sci. 15, 74-79 (in Chinese).

Tan, Y., Lu, Y., 2018. Responses of shallowly buried pipelines to adjacent deep excavations in Shanghai soft ground. J. Pipel. Syst. Eng. Pract. ASCE 9 (2), 05018002.

Xu, Y.S., Ma, L., Shen, S.L., Sun, W.J., 2012. Evaluation of land subsidence by considering underground structures that penetrate the aquifers of Shanghai, China. Hydrogeol. J. 20 (8), 1623- 
Wang, J.X., Huang, T., Hu, J., 2014. Field experiments and numerical simulations of whirlpool foundation pit dewatering. Environmental earth sciences, 71(7): 32-45.

Wang, J.X., Guo, T.P., Wu, L.G., et al., 2010. Mechanism and engineering application of wall well interaction in deep foundation pit dewatering. Journal of underground space and engineering, $6(03)$ : $564-570$.

Wang, J.X., Liu, X.T., Wu, Y, et al., 2017. Field experiment and numerical simulation of coupling non-Darcy flow caused by curtain and pumping well in foundation pit dewatering.Journal of Hydrology, 549: 277-293.

Wang, J.X., Wu, Y, Liu, X.t., et al., 2016. Areal subsidence under pumping well-curtain interaction in subway foundation pit dewatering: conceptual model and numerical simulations. Environmental

Wang, J.X., Feng, B., Guo, T., 2013. Using partial penetrating wells and curtains to lower the water level of confined aquifer of gravel. Engineering geology, 161: 16-25.

Wang, J.X., Hu, L, Wu, L., 2009. Hydraulic barrier function of the underground continuous concrete wall in the pit of subway station and its optimization. environmental geology, 2009. 57(2): 447-453.

Wu, Y.X., Lyu, H.M., Shen, J., Arulrajah, A., 2018. Geological and hydrogeological environment in 
658

659

660

661

662

663

664

665

666

667

deep excavation in soft deposit in Tianjin, China. J. Geotech. Geoenviron. Eng. 145 (5), 5019003. https://doi.org/10.1061/(ASCE)GT.1943-5606.0002045.

Wang, X.W., Yang, T.L., Xu, Y.S., et al., 2019.Evaluation of optimized depth of waterproof curtain to mitigate negative impacts during dewatering, Journal of Hydrology, 577.

Ye, W.M., Wan, M., Chen, B., et al., 2009. Influence of dewatering in confined aquifer of deep foundation pit on land subsidence. Acta subterranean space and engineering, (S2): 1799-1805.

You, Y., Yan, C.h., Liu, S., et al., 2017. Optimization design of dewatering scheme for a deep foundation pit under complex geological conditions. Acta geologica Sinica, 25 (3): 715-722.

Zhao, Y.H., Tong, L.Y., Zhu, W.J., et al., 2020. Prediction and analysis of the impact of foundation pit dewatering under different waterproof curtain insertion depths on the surrounding environment. Water conservancy and hydropower technology, 51 (05): 126-131.

Zheng, G., Dai, X., Diao, Y., Zeng C.F., 2016. Experimental and simplified model study of the development of ground settlement under hazards induced by loss of groundwater and sand. Nat. Hazards 82 (3), 1869-1893.

Zhang, M., Fan, J., Zhao, Y.R., 2019. Study on the influence of subway station reconstruction dewatering on adjacent rail transit. Water conservancy and hydropower technology, 50 (2): 61-68. 


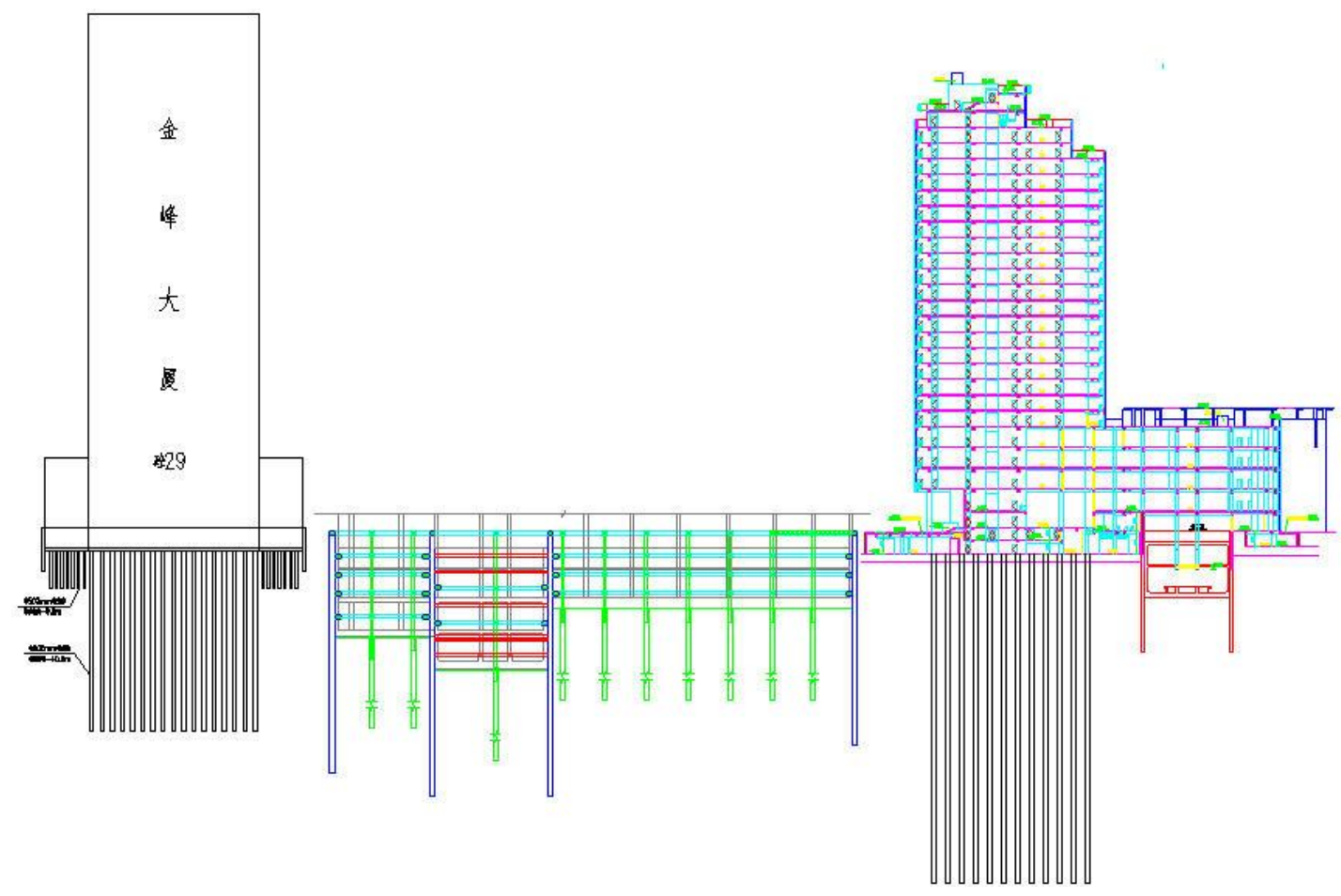

Fig. 1 Curtain cutoff, pumping and recharging measures to control groundwater level for excavation 


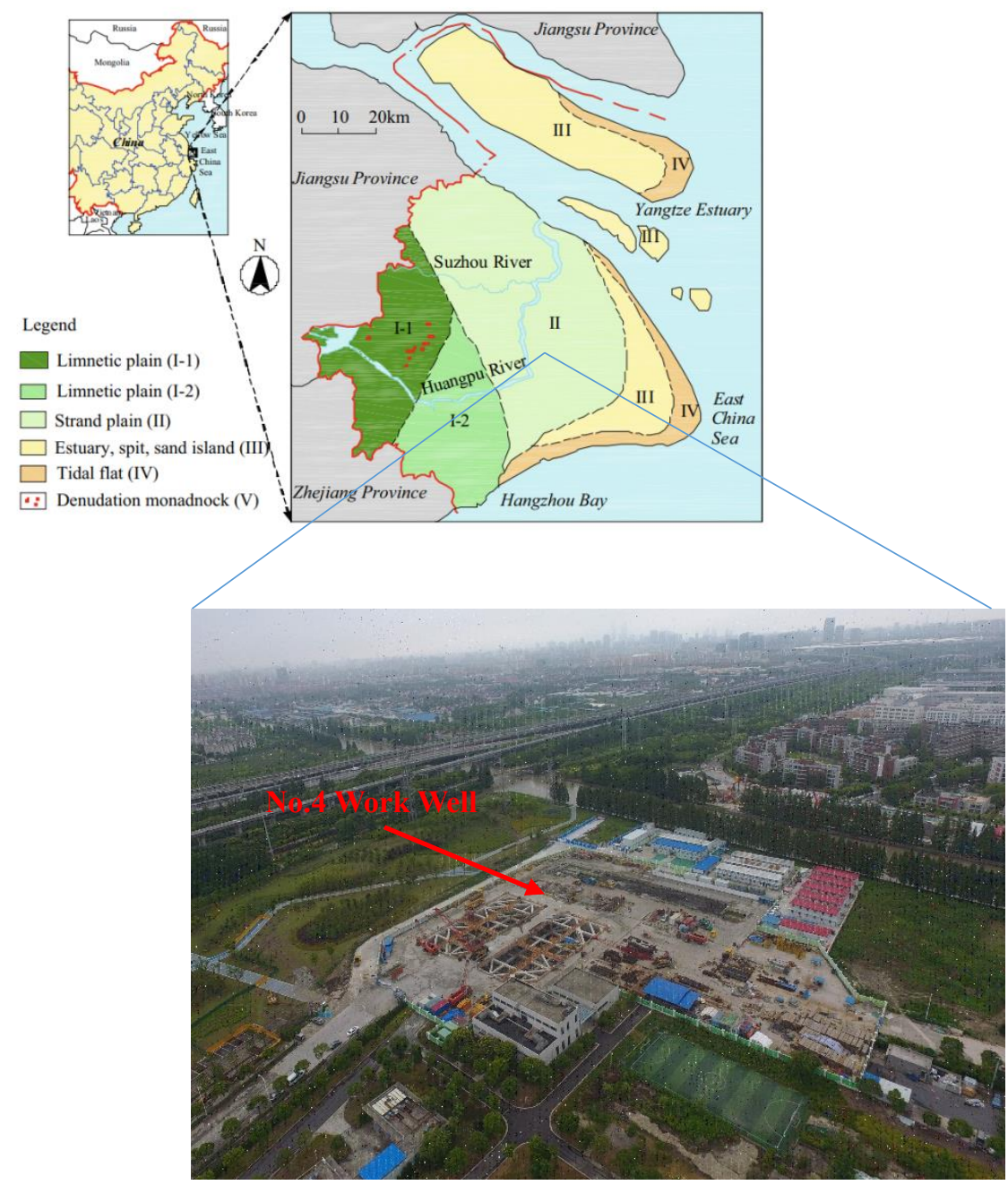

(a) Background working well base
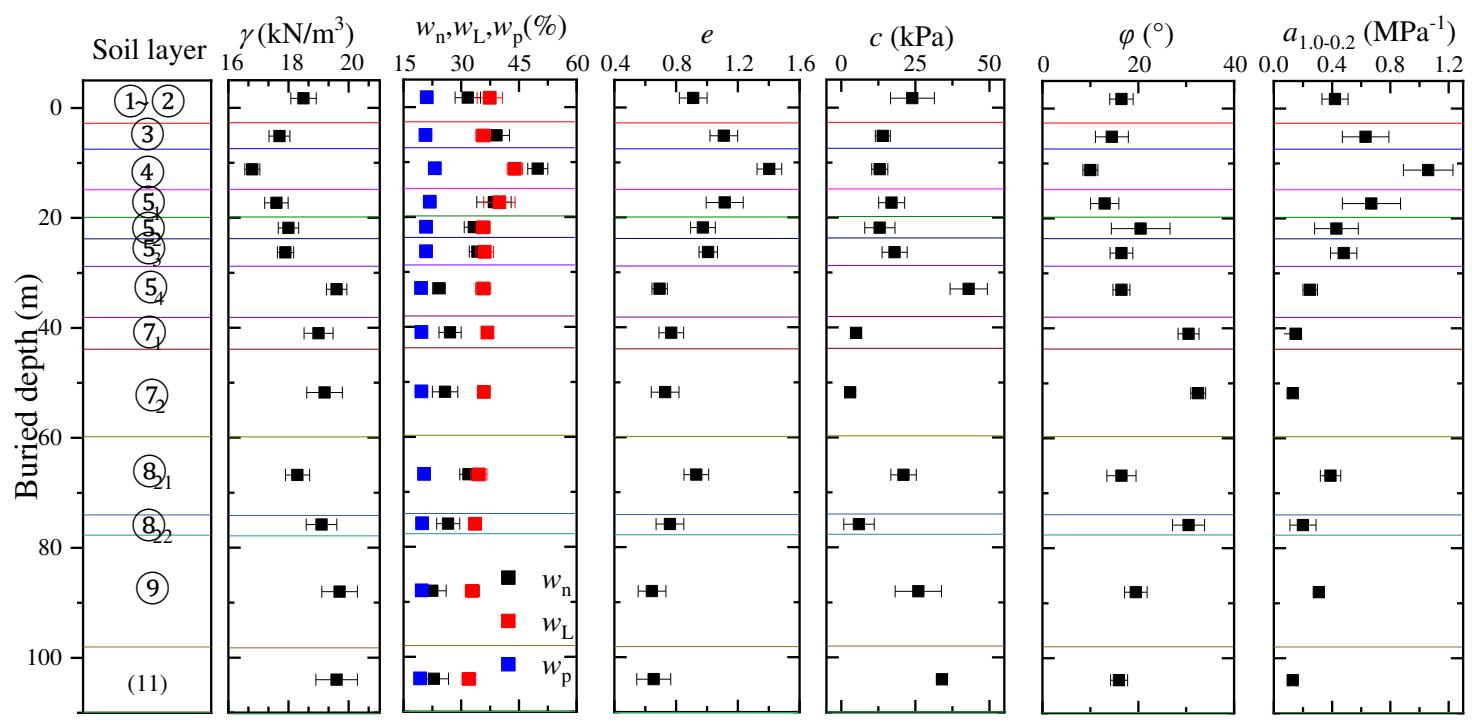

Note: $\gamma=$ unit weight; $w_{\mathrm{n}}=$ water content; $w_{\mathrm{p}}=$ plastic limit; $w_{\mathrm{L}}=$ liquid limit; $e=$ void ratio; $a_{0.1-0.2}=$ coeffient of compressibility; $c=$ cohesion $; \varphi=$ internal friction angle

(b) Hydrogeological Profile

Fig. 2 Layout of the No. 4 working shaft background 


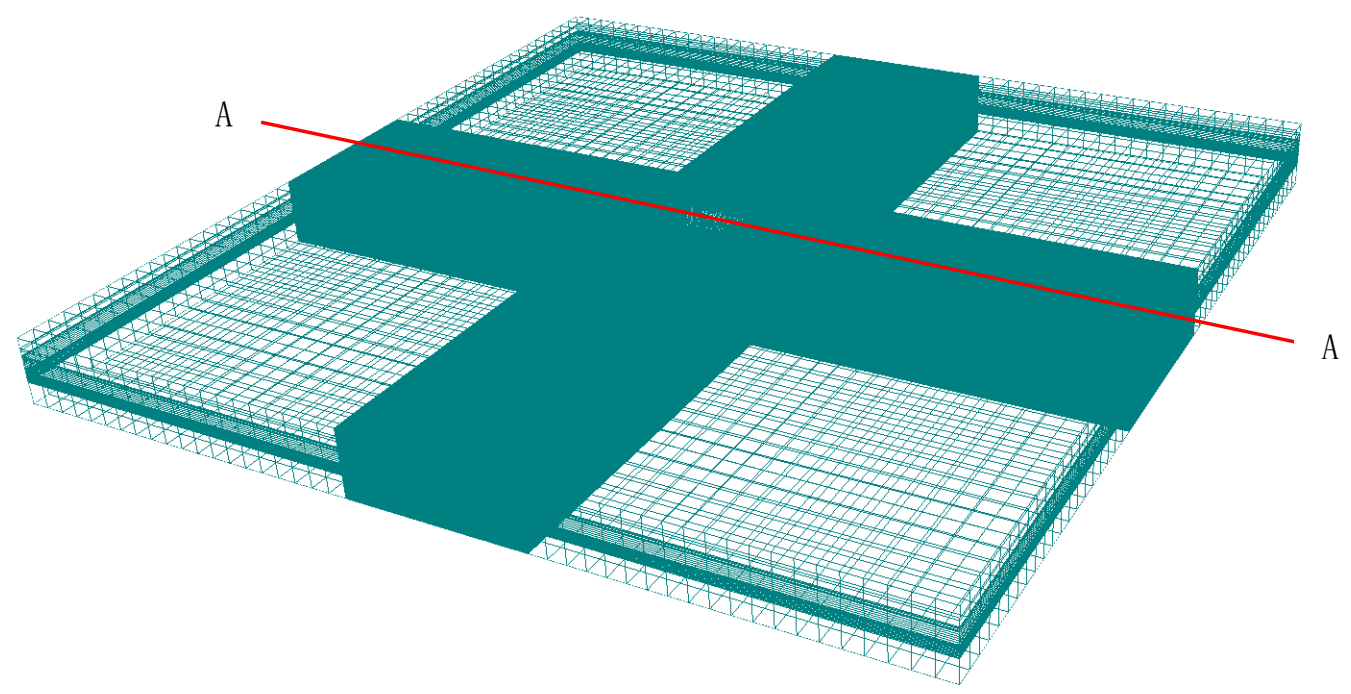

(a) 3D grid of the model

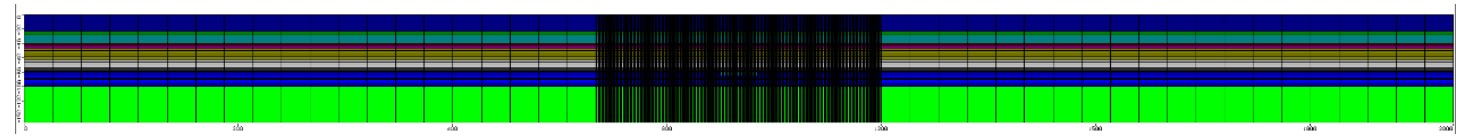

(b) Section A-A'

Fig.3 Numerical model of the MICP HSRB 


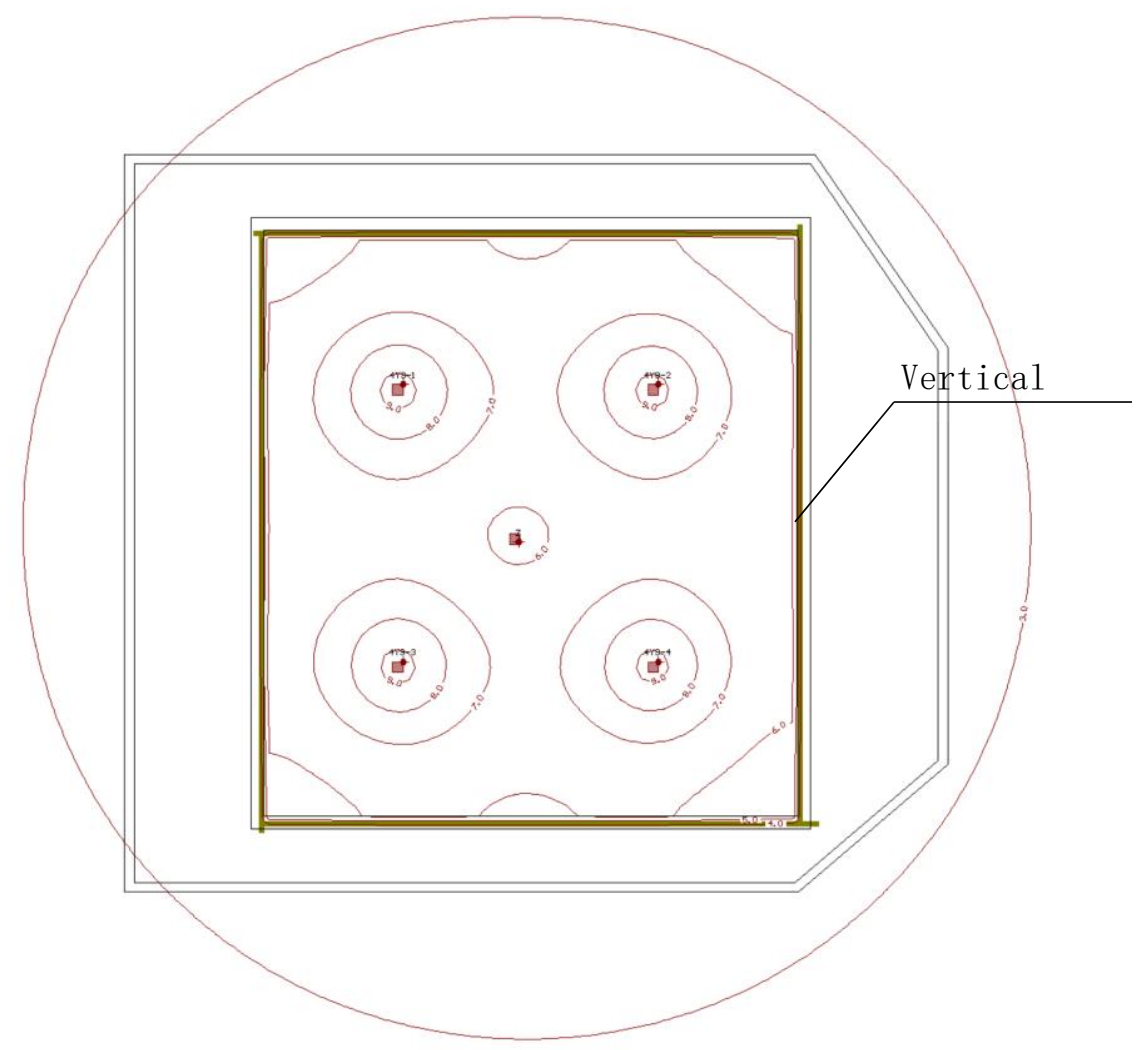

(a) Layer(8) $2-2$

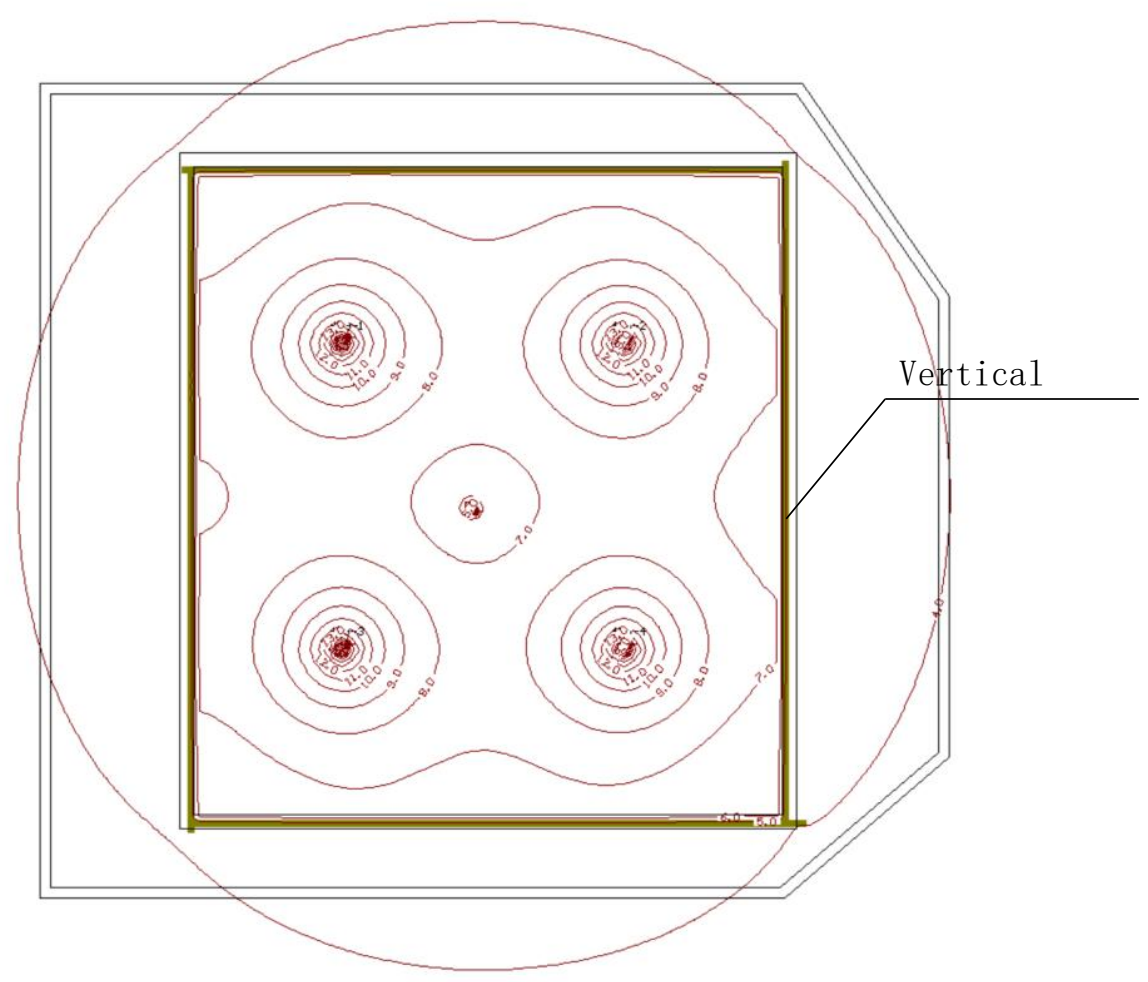

(b) Layer (9)

Fig.4 Contour map of the aquifer drawdown 


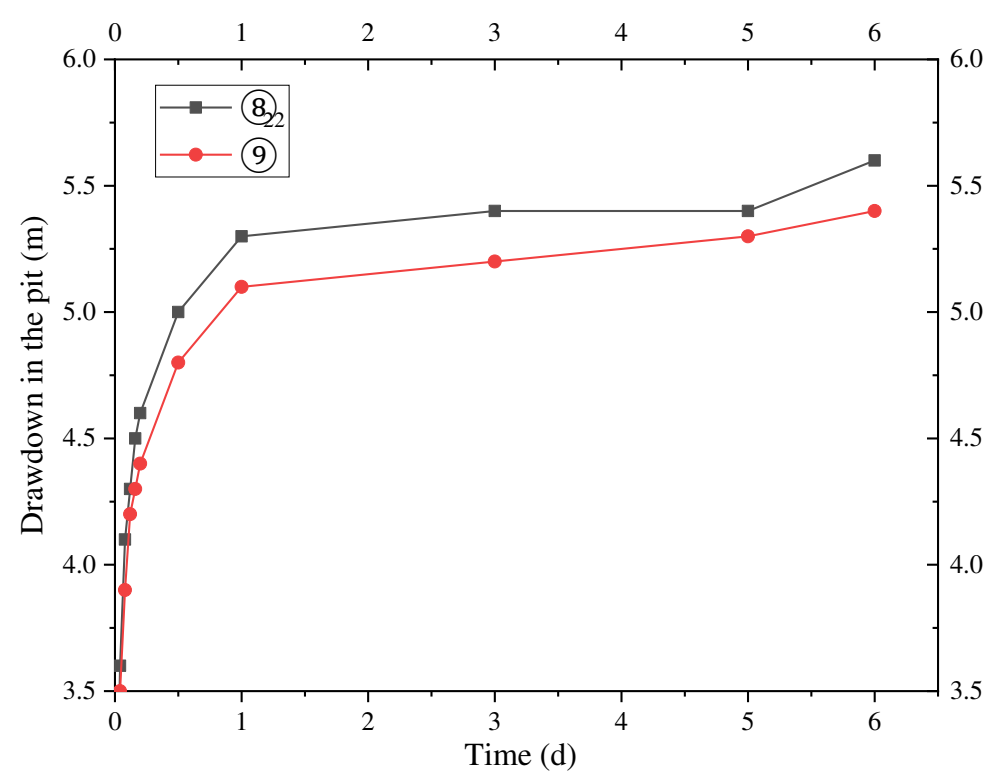

(a) Inside the pit

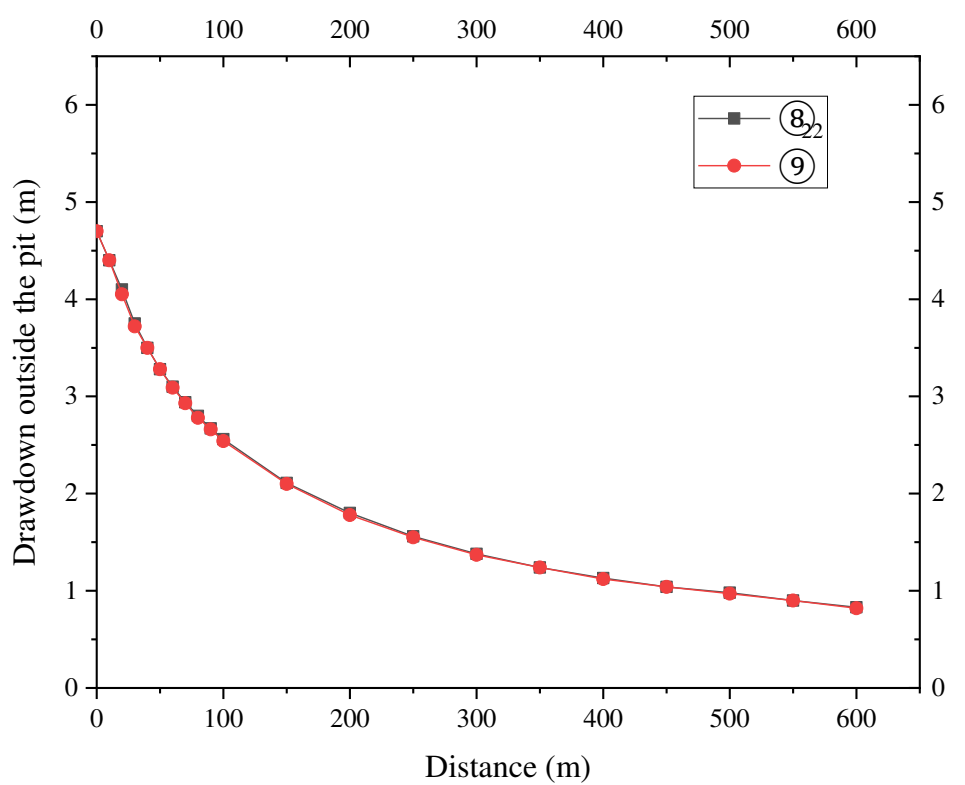

(b) Outside the pit

Fig. 5 Variation curve of the drawdown with distance 


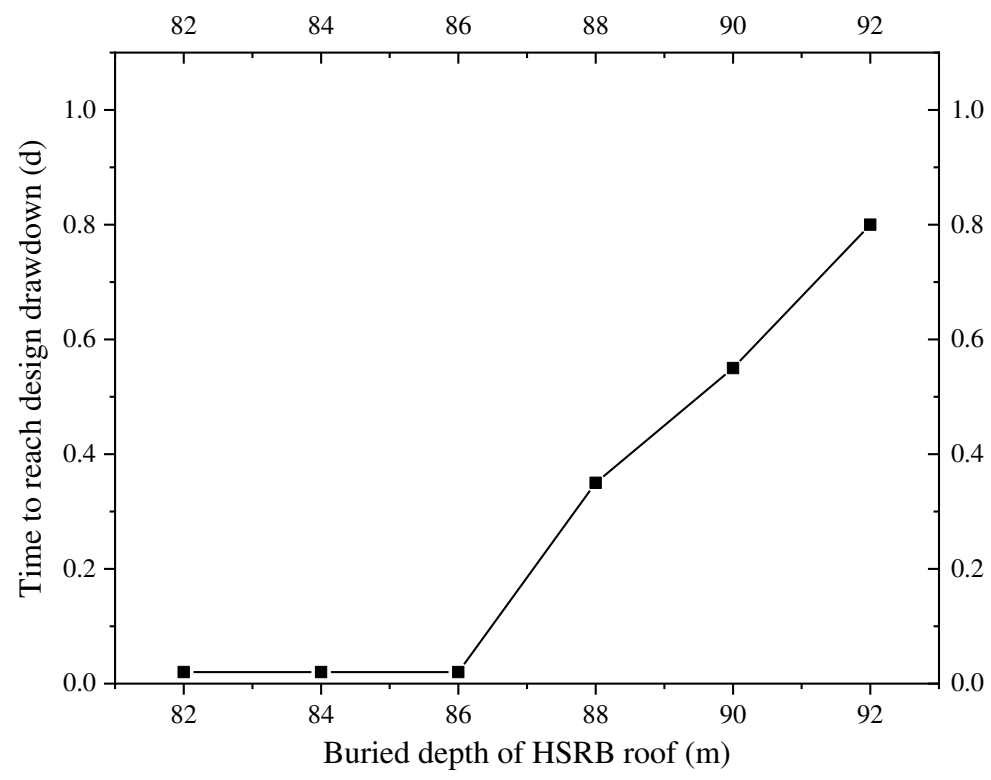

Fig.6 Time chart of the dewatering reaching the design depth of each working condition 


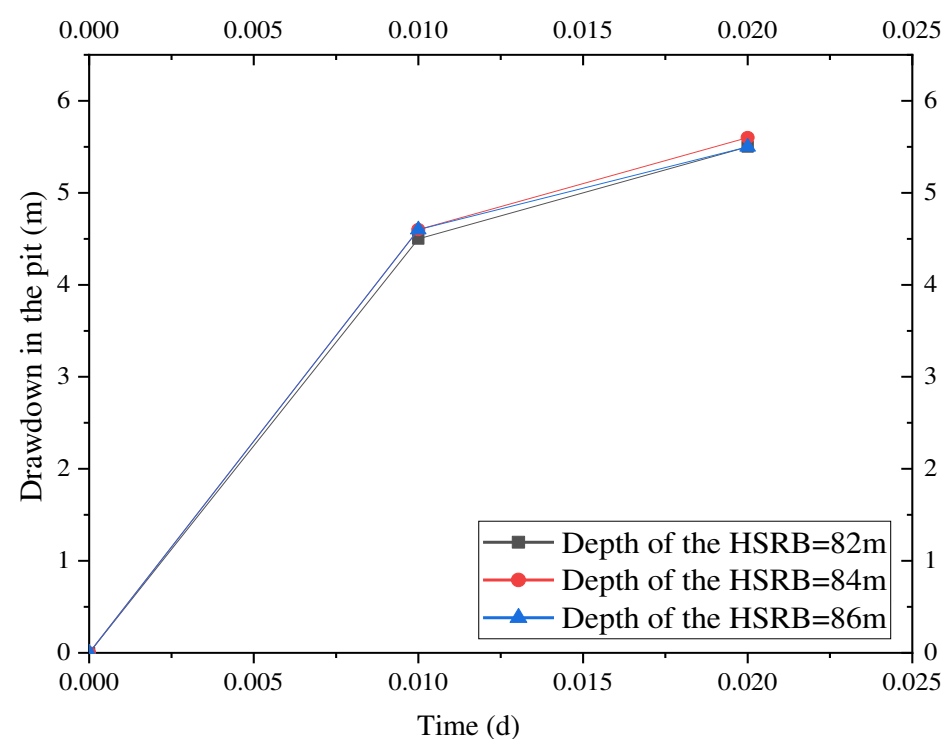

(a) Layer $8_{22}$

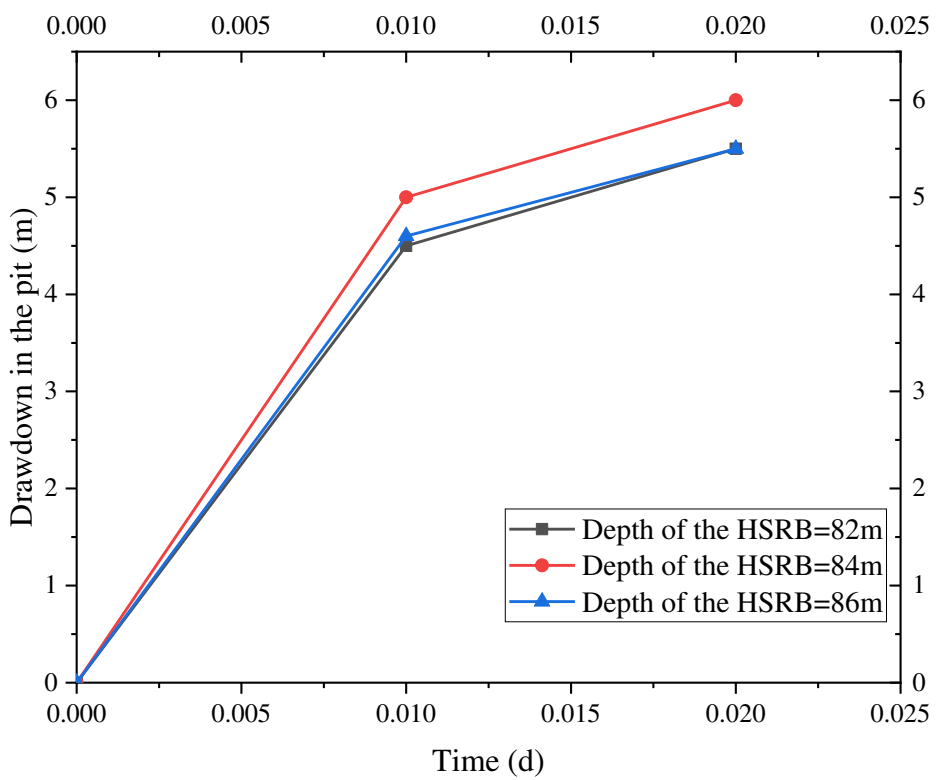

(b) Layer (9) 


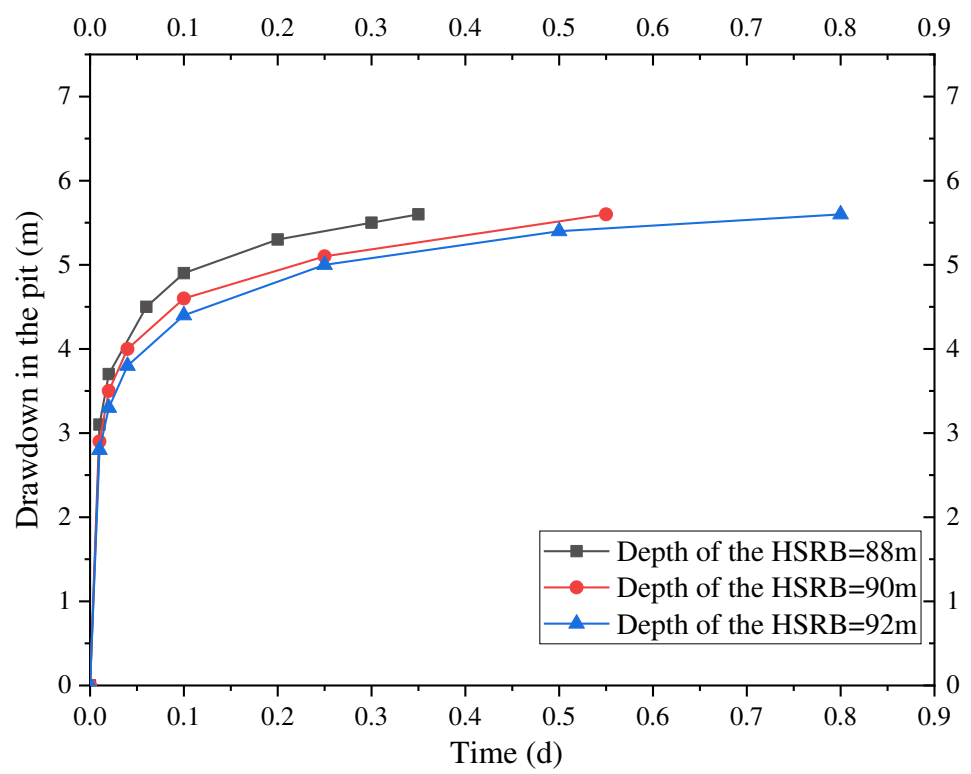

(c) Layer 8$)_{22}$

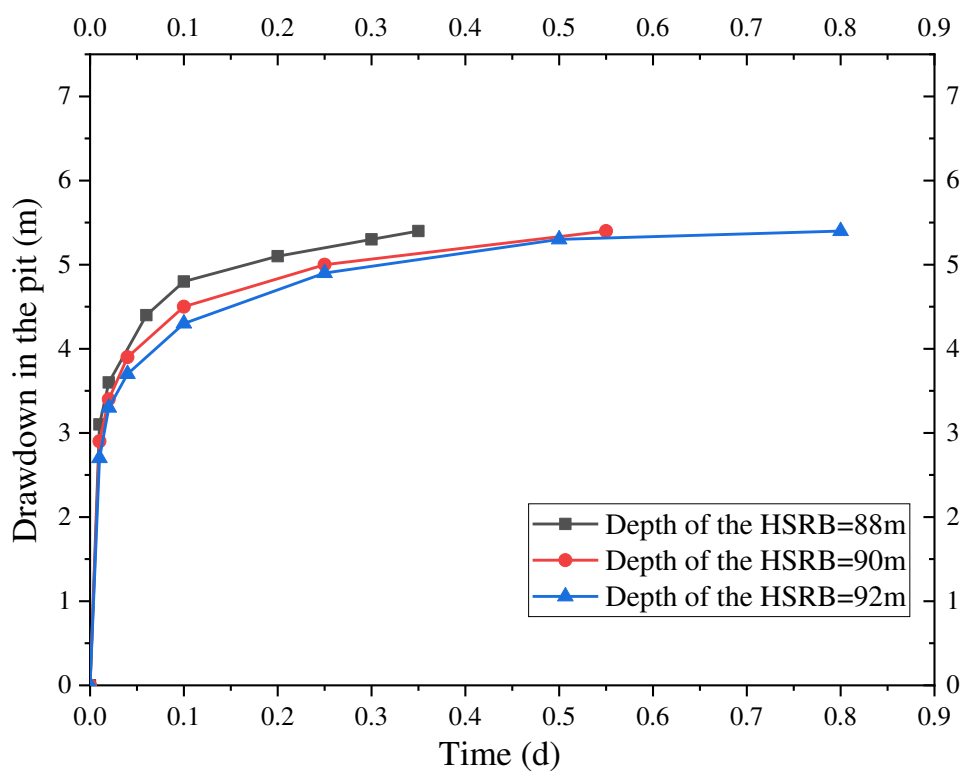

(d) Layer (9)

Fig. 7 Drawdown-time curve in the pit with different HSRB positions 


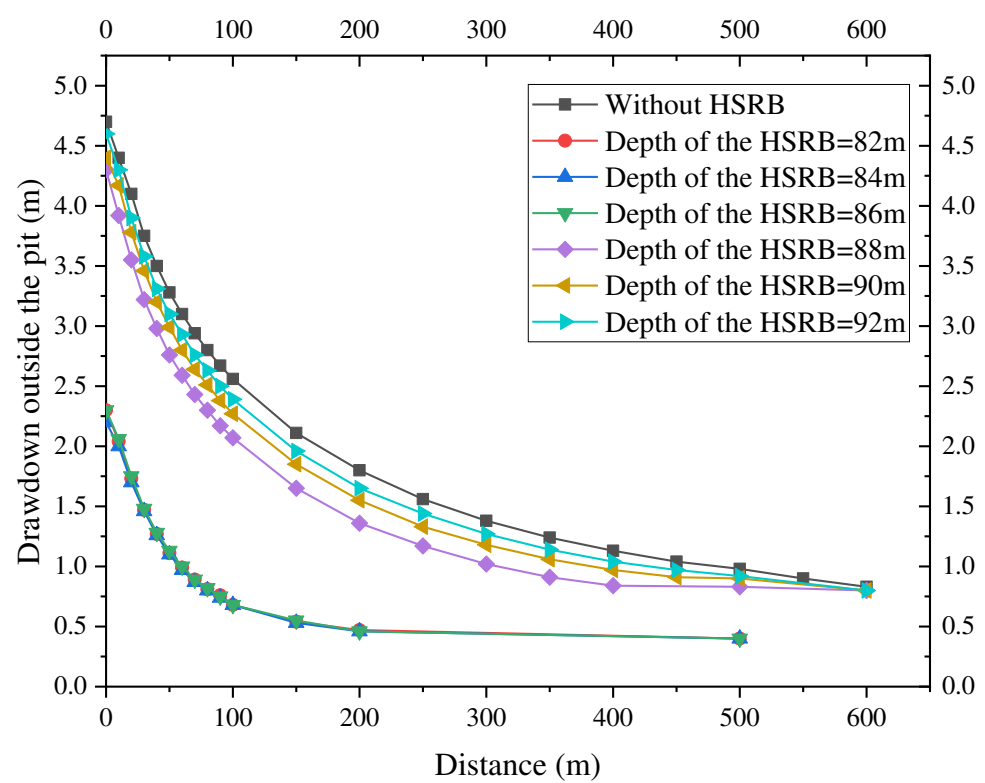

(a) Layer $8_{22}$

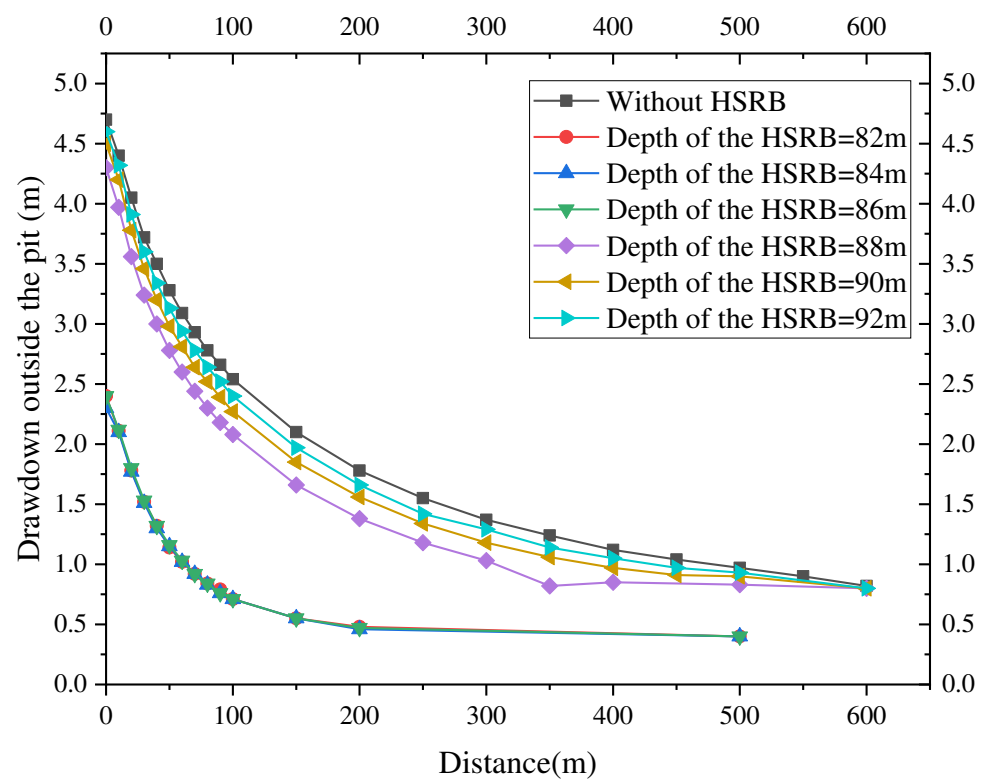

(b) Layer (9)

Fig. 8 Drawdown-distance curve outside the pit with different HSRB positions 


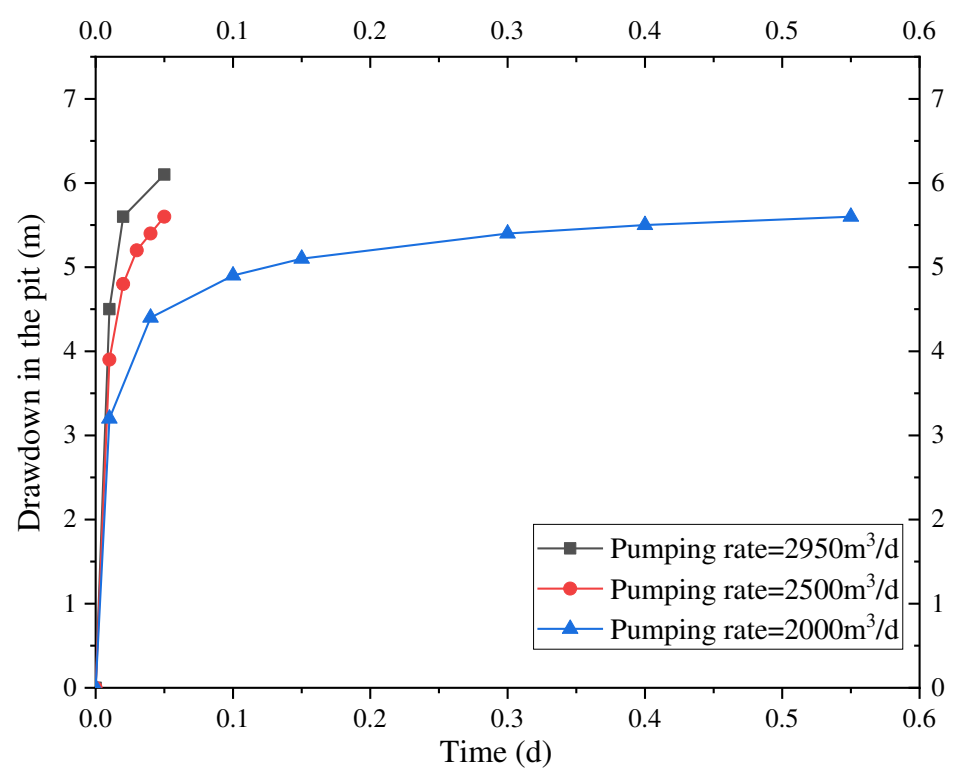

(a) Layer $8_{22}$

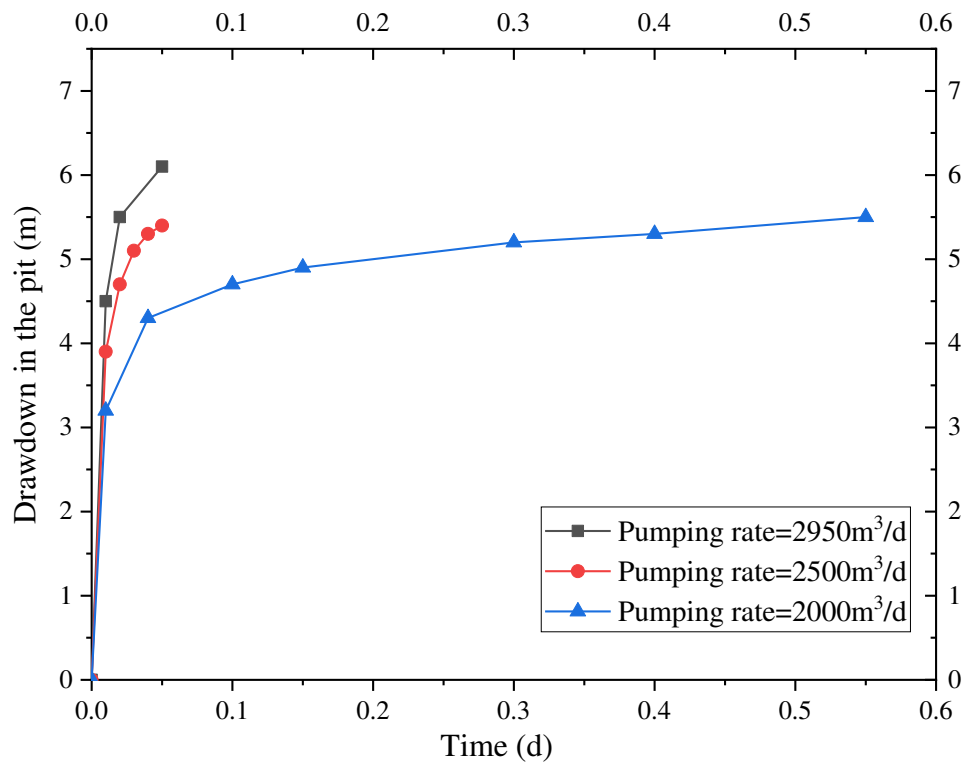

(b) Layer (9)

Fig. 9 Drawdown-time curve in the pit with different pumping rates 


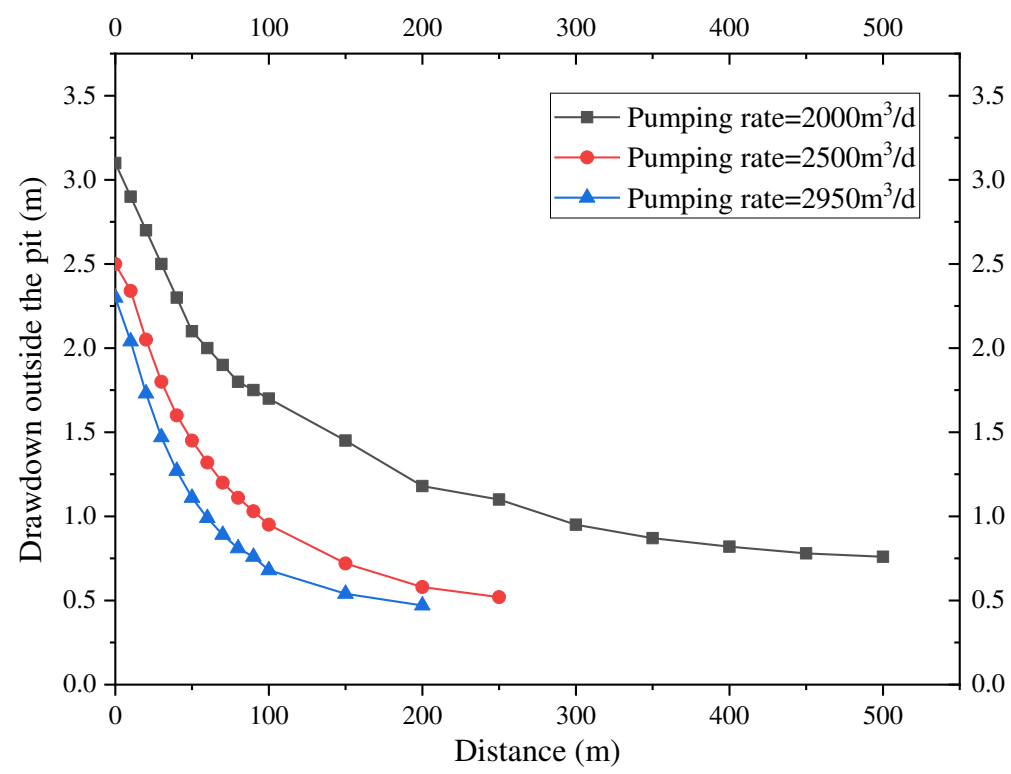

(a) Layer $8_{22}$

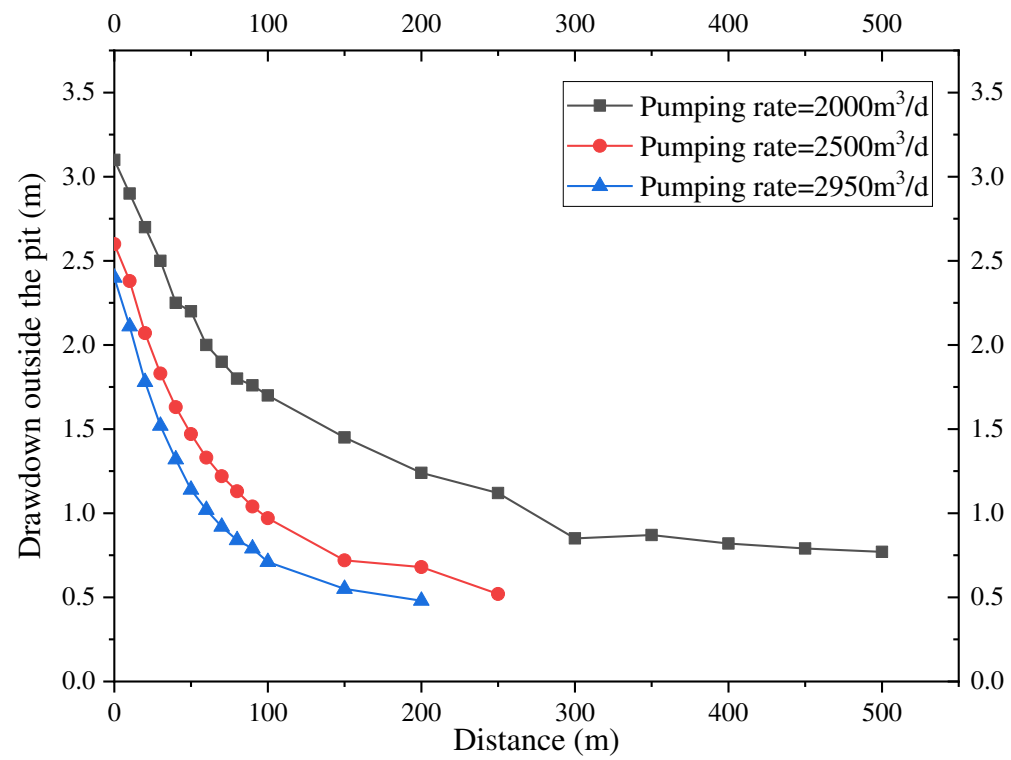

(b) Layer (9)

Fig. 10 Drawdown-distance curve outside the pit with different pumping rates 


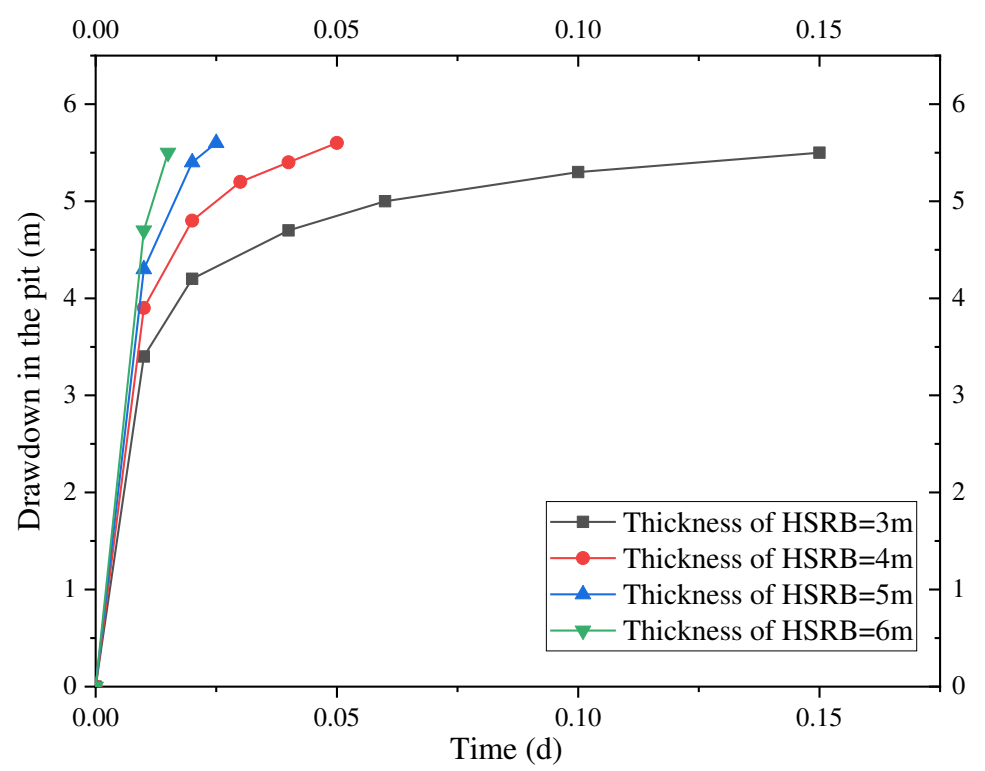

(a) Layer $8_{22}$

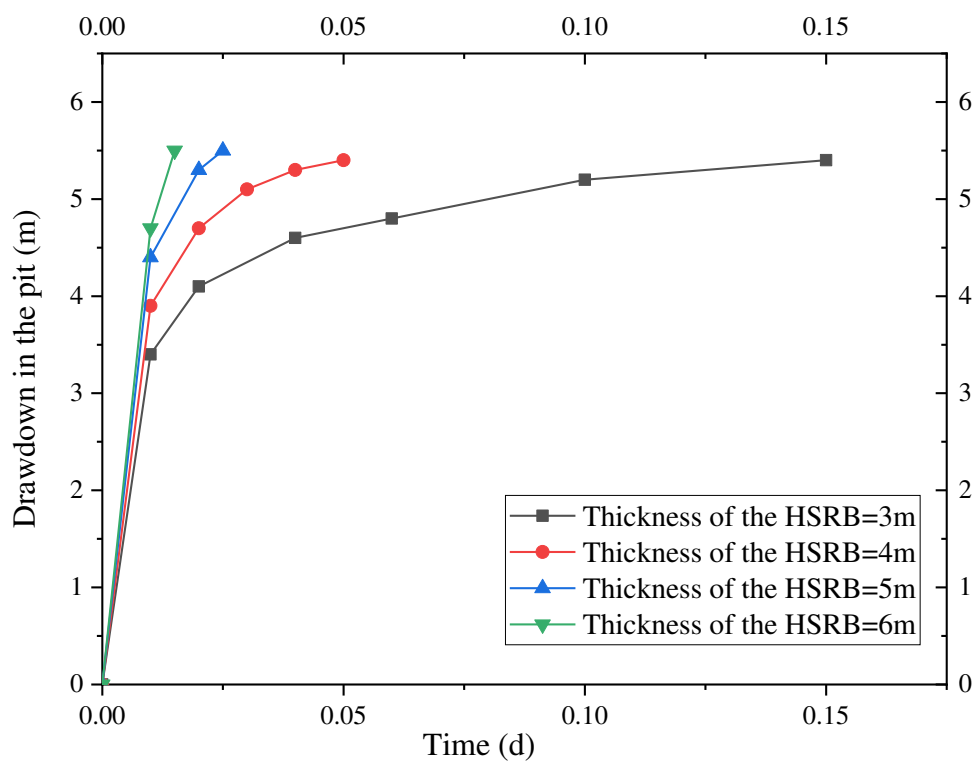

(b) Layer (9)

Fig. 11 Drawdown-time curve in the pit with different HSRB thicknesses 


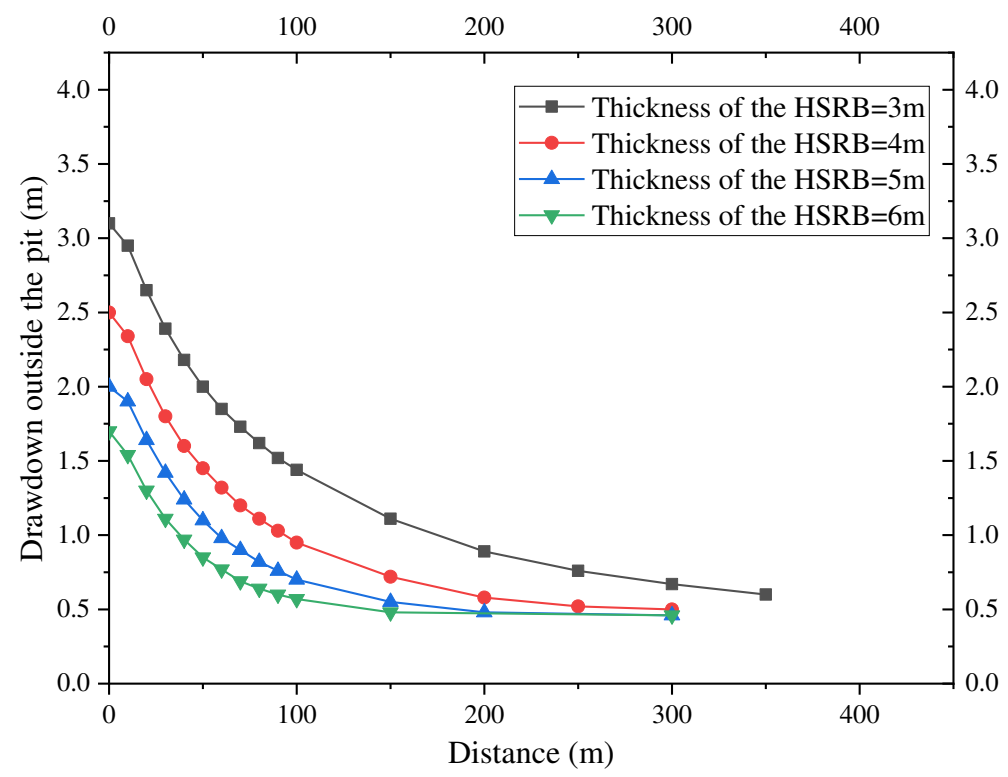

(a) Layer $8_{22}$

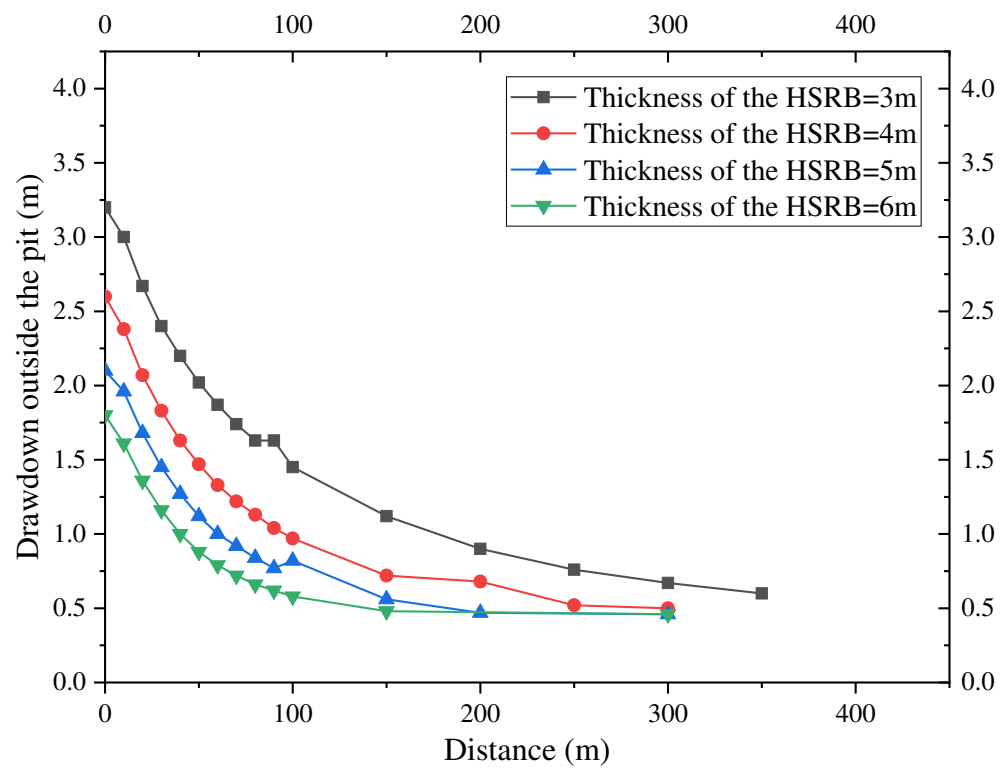

(b) Layer (9)

Fig. 12 Drawdown-distance curve outside the pit with different HSRB thicknesses 


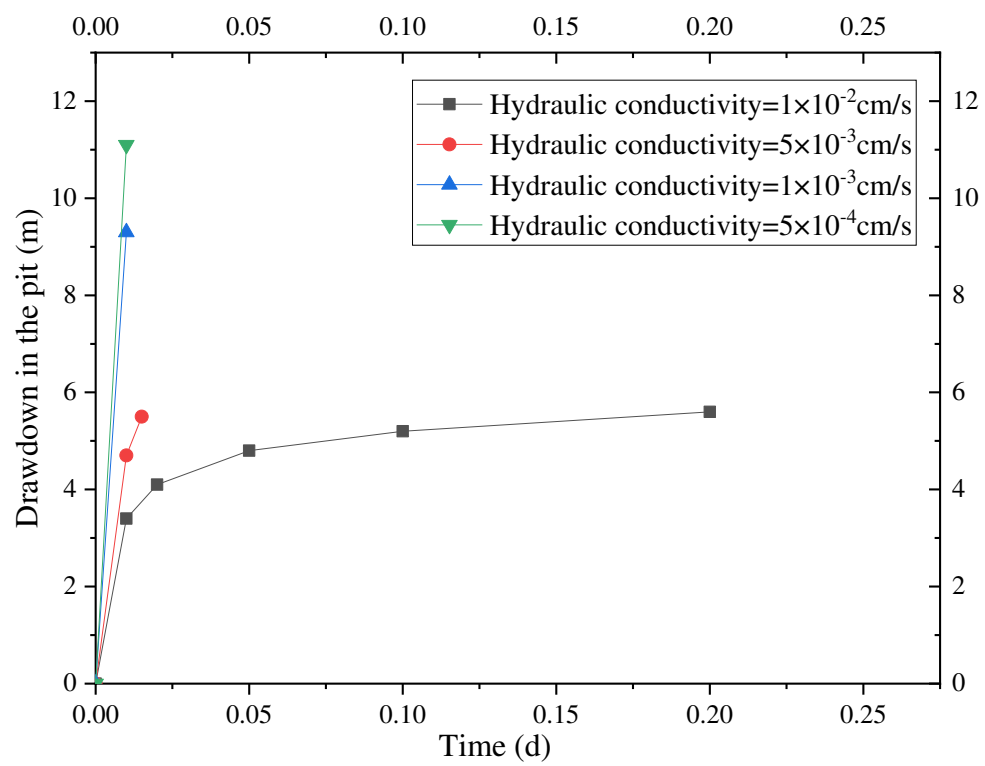

(a) Layer 8$)_{22}$

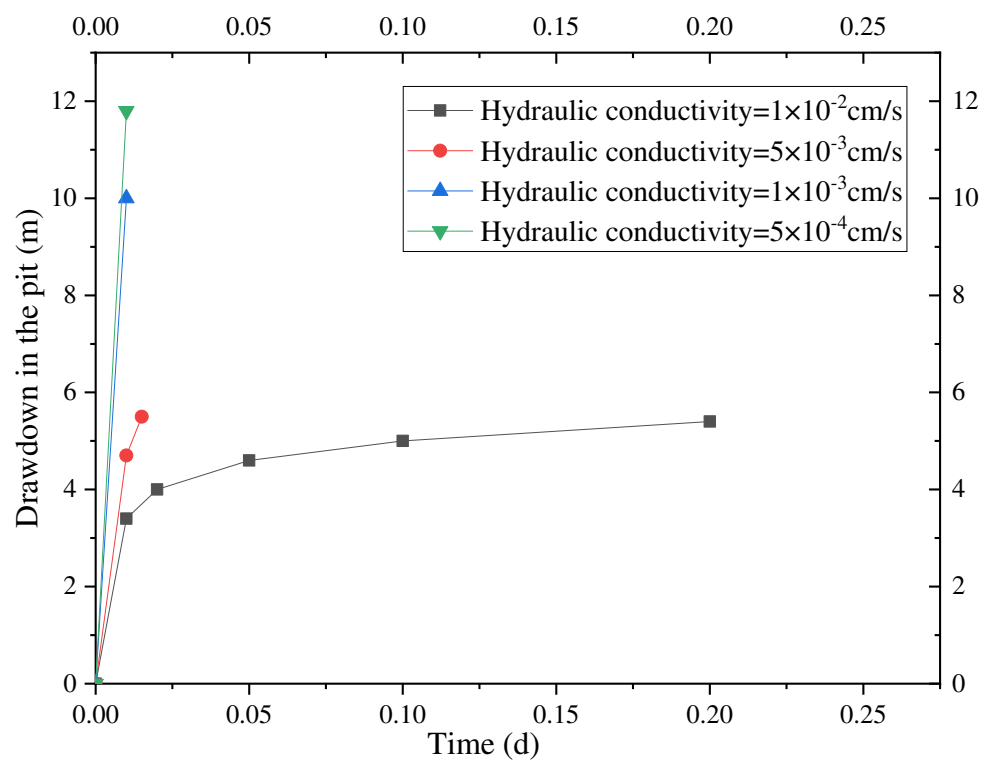

(b) Layer (9)

Fig.13 Drawdown-time curve in the pit with different hydraulic conductivities 


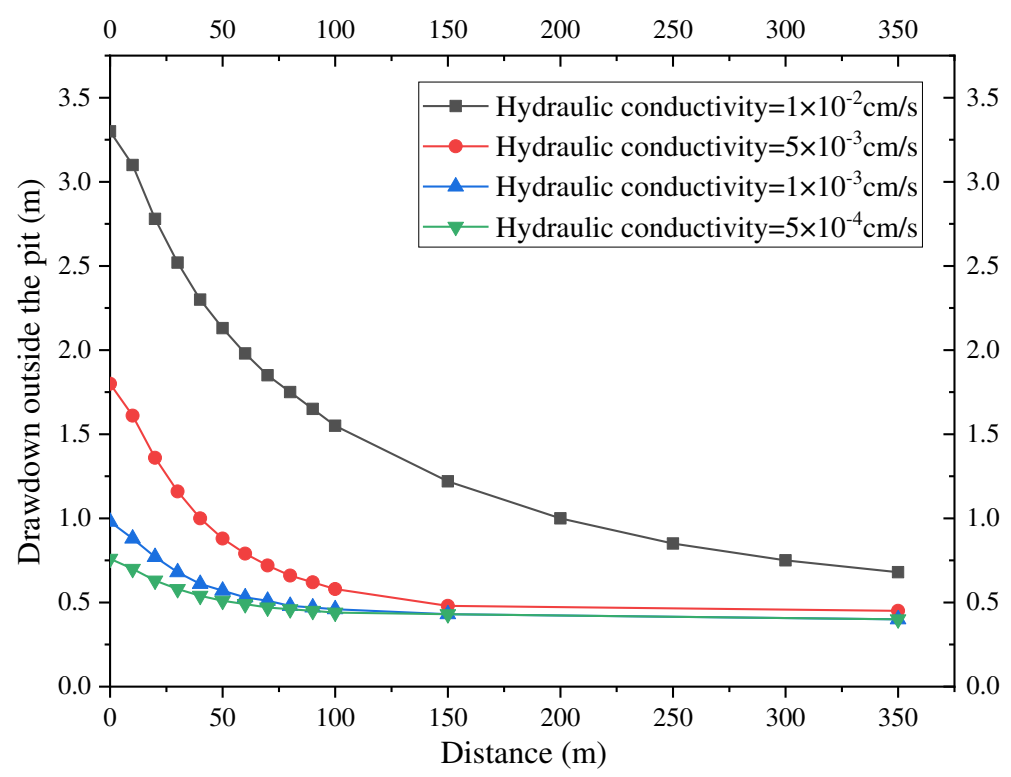

(a) Layer 8$)_{22}$

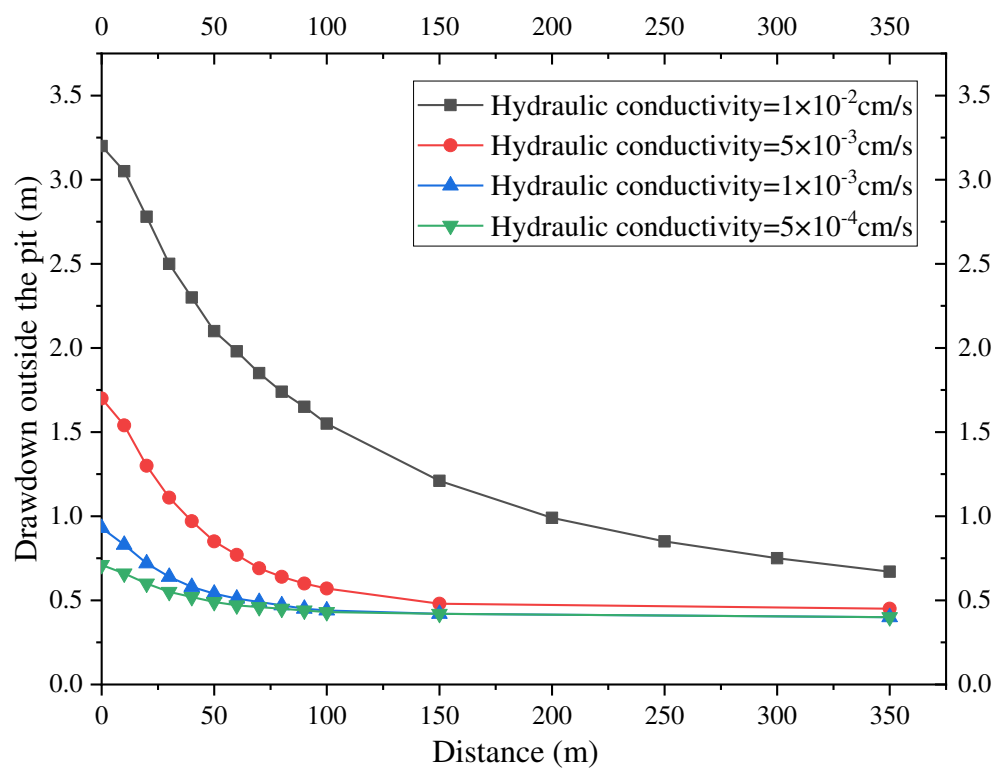

(b) Layer (9)

Fig. 14 Drawdown-time curve outside the pit with different hydraulic conductivities 

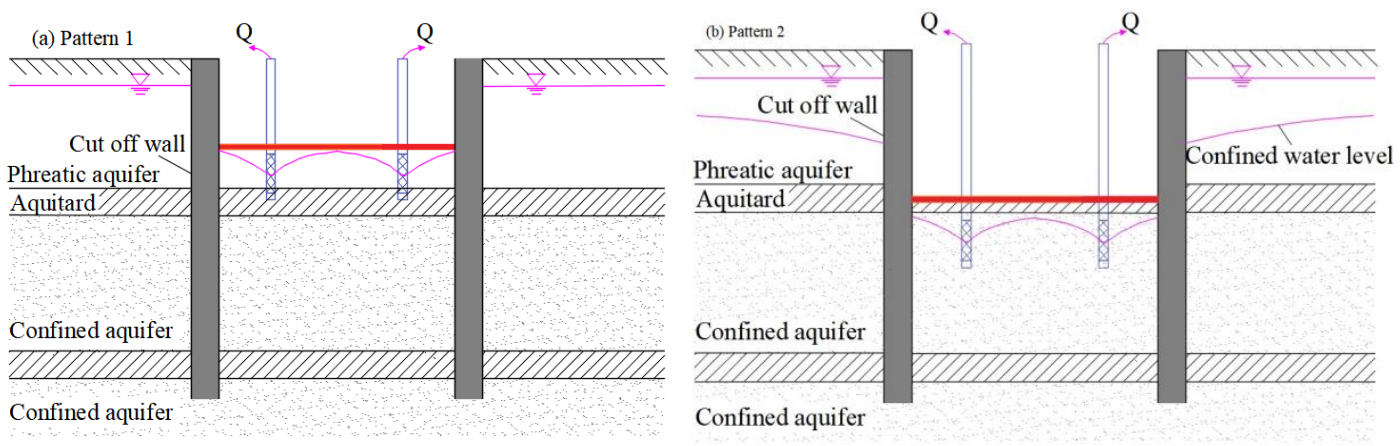

1) Mode I

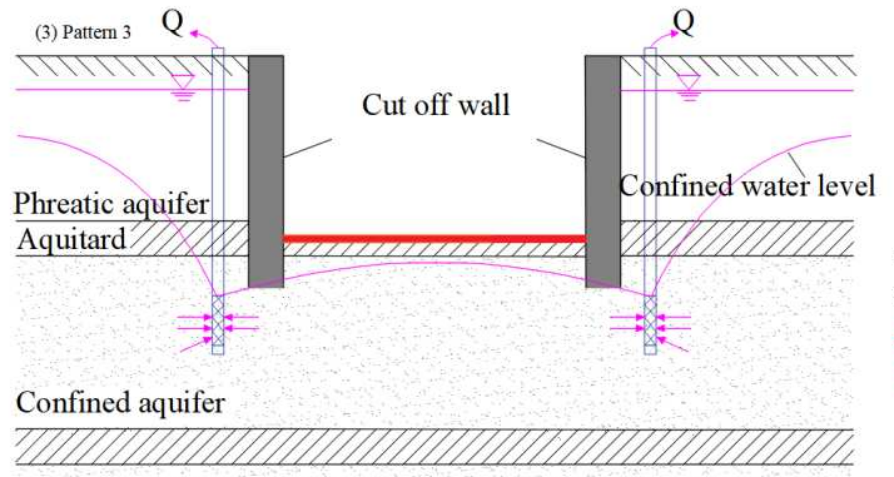

Legend

Cut off wall

] Dewatering well

Well screen

Confined aquifer

(19m) Aquitard

- Excavation face

$\nabla$ Phreatic aquifer lever

Confined aquifer

2) Mode II

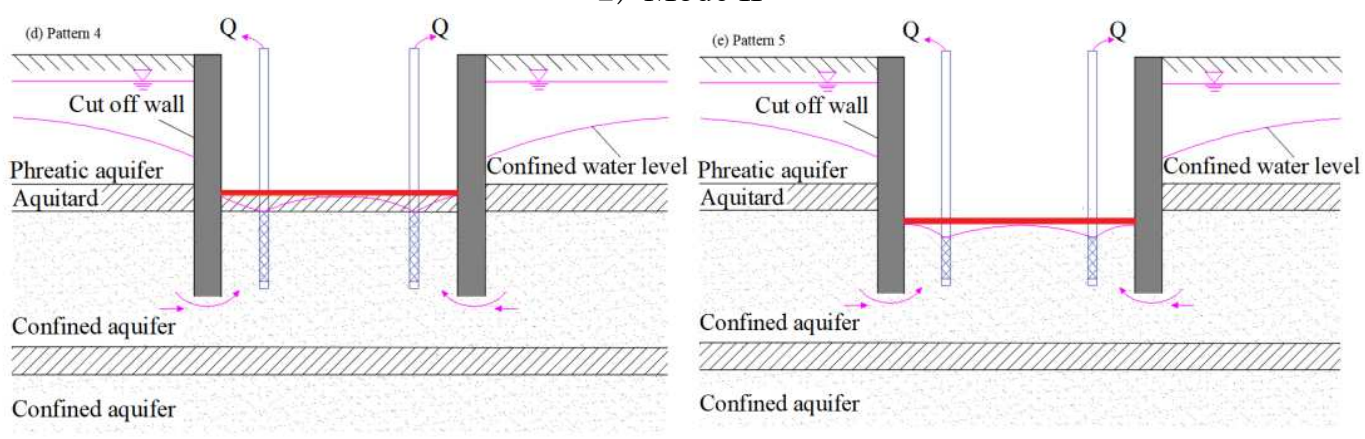

3) Mode III

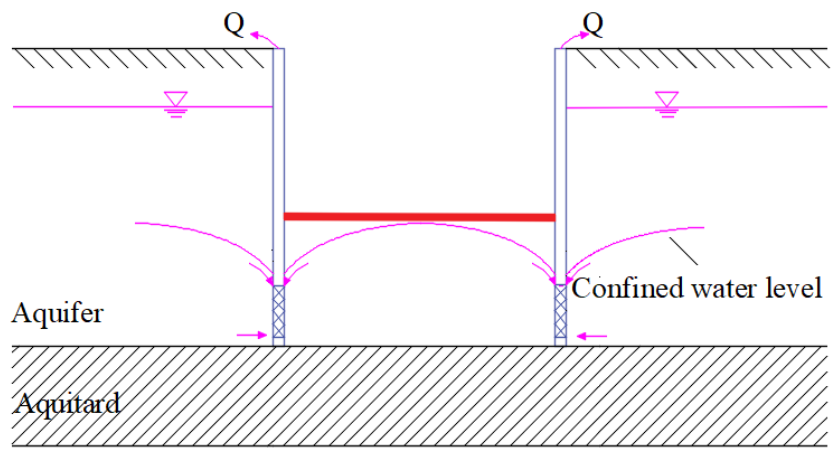

4) Mode IV

Fig. 15 Conceptual model of four summarized seepage modes 


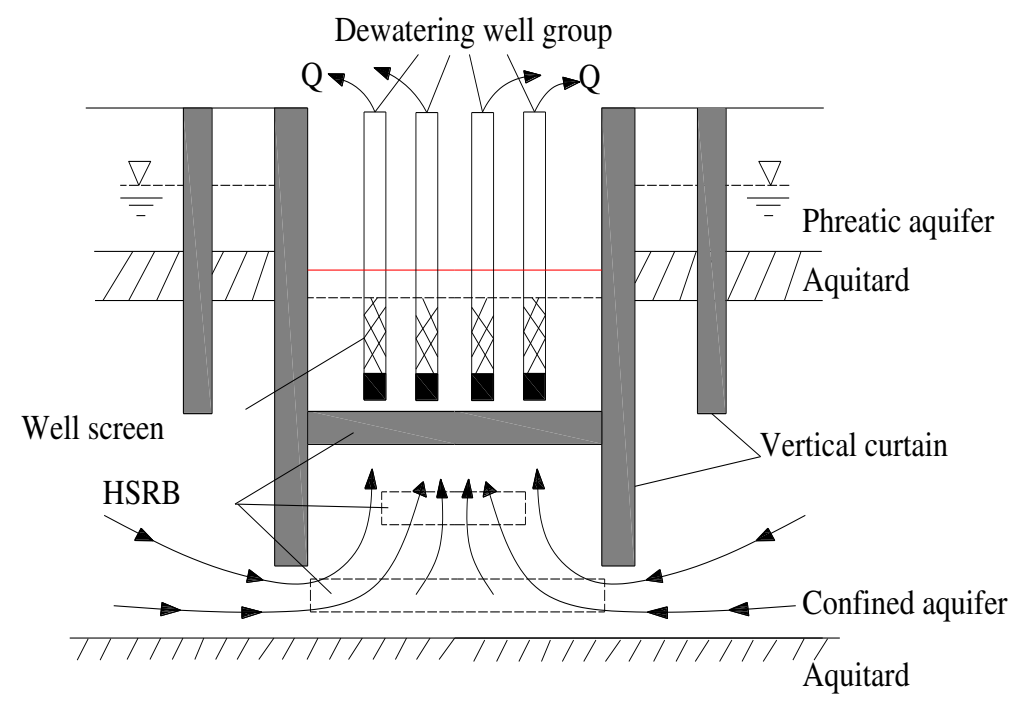

Fig. 16 Conceptual model of three-dimensional curtain-well group system
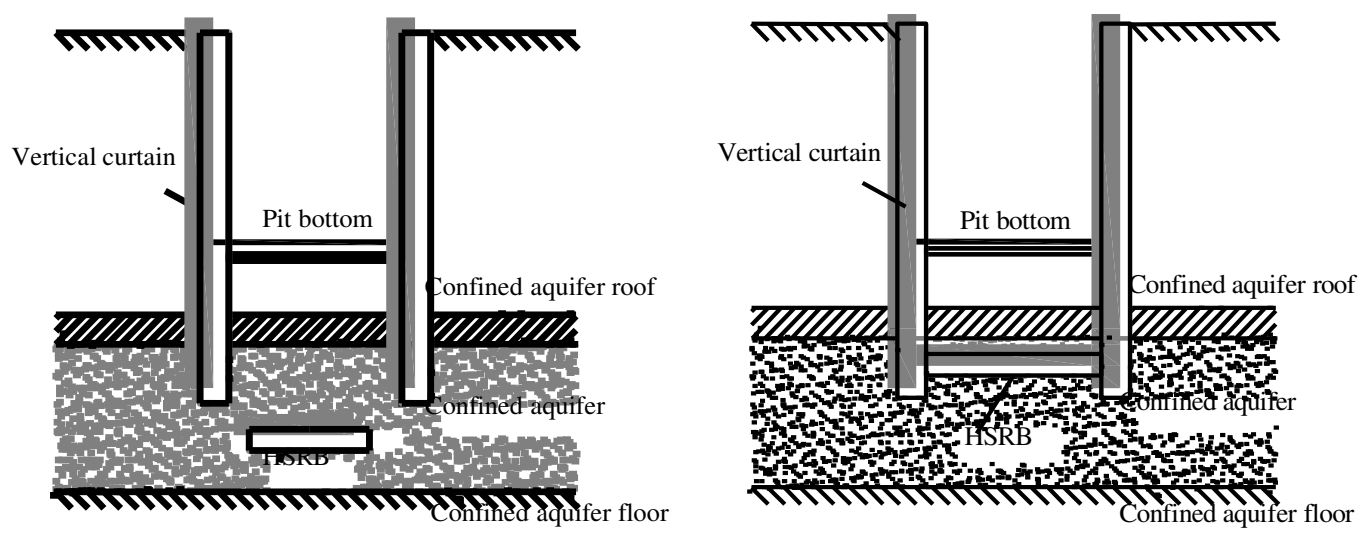

(a) V-1:Separated three-dimensional curtain

(b) V-2: Inner-wrapped three-dimensional curtain
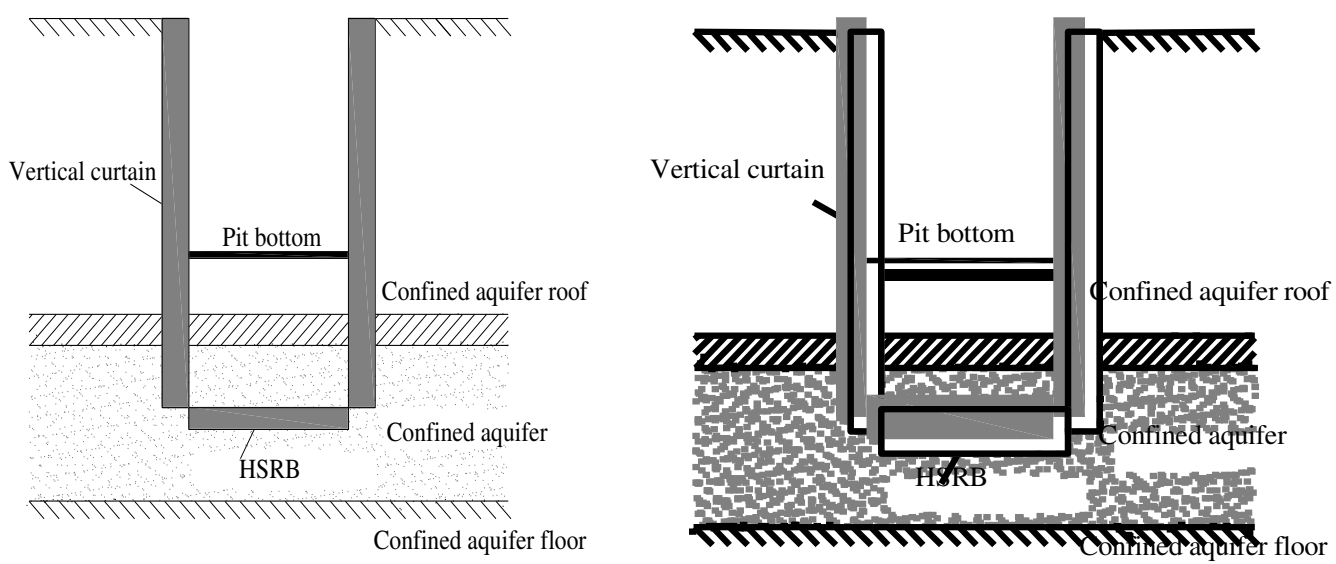

(c) V-3:Flush three-dimensional curtain (d) V-4:Transitional three-dimensional curtain Fig. 17 Combination sub-mode of vertical curtain and HSRB 


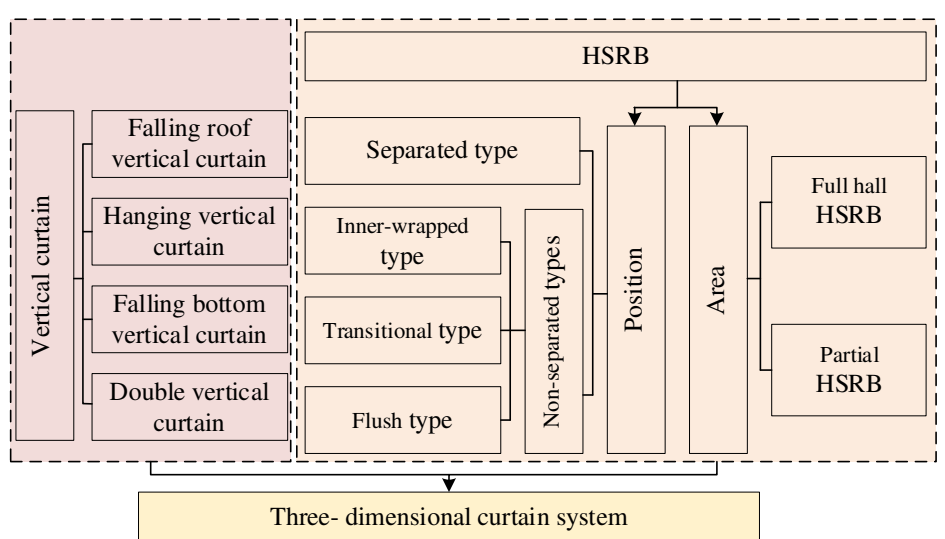

Fig. 18 Framework of the three-dimensional curtain concept system 
Table 1 Hydraulic conductivity of the soil layers

\begin{tabular}{cccc}
\hline Layer & Soil & $\begin{array}{c}\text { Hydraulic } \\
\text { conductivity } \\
(\mathrm{cm} / \mathrm{s})\end{array}$ & Ss $(1 / \mathrm{m})$ \\
\hline$/$ & Shallow clay layer & $5.0 \times 10^{-5}$ & $8.0 \times 10^{-4}$ \\
$(5)_{2}$ & Clayey silt with silty clay & $3.0 \times 10^{-4}$ & $4.5 \times 10^{-4}$ \\
$(5)_{3}$ & Silty clay & $8.0 \times 10^{-5}$ & $8.0 \times 10^{-3}$ \\
$(5)_{4}$ & Silty clay & $4.0 \times 10^{-5}$ & $8.0 \times 10^{-3}$ \\
$(7)_{1}$ & Sandy silt & $1.48 \times 10^{-3}$ & $4.5 \times 10^{-4}$ \\
$(7)_{2}$ & Silt & $1.40 \times 10^{-3}$ & $5.0 \times 10^{-4}$ \\
$(8)_{21}$ & Interlayer of silty clay and & $6.0 \times 10^{-5}$ & $4.5 \times 10^{-4}$ \\
$\left(88_{22}\right.$ & Silty sand with silty clay & $6.4 \times 10^{-3}$ & $5.0 \times 10^{-4}$ \\
$(9)$ & Silt & $5.0 \times 10^{-2}$ & $2.0 \times 10^{-5}$ \\
$(11)$ & Silt & $1.0 \times 10^{-2}$ & $3.0 \times 10^{-5}$ \\
\hline
\end{tabular}


Table 2 Statistical table for the layout of dewatering wells in foundation pit

\begin{tabular}{|c|c|c|c|c|c|c|c|}
\hline Position & Well type & soil layers & depth & Quantity & $\begin{array}{l}\text { Aperture/well diameter/well pipe } \\
\text { thickness }\end{array}$ & Well No. & $\begin{array}{c}\text { Thickness of clay } \\
\text { ball }\end{array}$ \\
\hline \multirow{8}{*}{ In pit } & Dewatering well & (1) (5) 3 & 38 & 12 & $650 / 273 / 4 \mathrm{~mm}$ & $4 \mathrm{~J}-1 \sim 4 \mathrm{~J}-12$ & 0 \\
\hline & Depressurization well & \multirow{4}{*}{ (7) (8) 21} & 68 & 1 & $650 / 273 / 6 \mathrm{~mm}$ & 4Y7-1 & $8 \mathrm{~m}$ \\
\hline & Depressurization well & & 63 & 1 & $650 / 273 / 6 \mathrm{~mm}$ & $4 Y 7-2$ & $8 \mathrm{~m}$ \\
\hline & Observation well & & 60 & 1 & $650 / 273 / 6 \mathrm{~mm}$ & $4 \mathrm{G} 7-1$ & $8 \mathrm{~m}$ \\
\hline & Observation well & & 70 & 1 & $650 / 273 / 6 \mathrm{~mm}$ & 4G8-1 & $8 \mathrm{~m}$ \\
\hline & Depressurization well & \multirow{3}{*}{ (8) $22 \sim 9)$} & 85 & 3 & $850 / 400 / 8 \mathrm{~mm}$ & $4 Y 9-1 \sim 4 Y 9-3$ & \multirow{3}{*}{$10 \mathrm{~m}$} \\
\hline & Spare well & & 85 & 1 & $850 / 400 / 8 \mathrm{~mm}$ & 4YB9-1 & \\
\hline & Observation well & & 85 & 1 & $850 / 400 / 8 \mathrm{~mm}$ & 4G9-1 & \\
\hline \multirow{2}{*}{$\begin{array}{l}\text { Between } \\
\text { two walls }\end{array}$} & $\begin{array}{c}\text { Spare and observation } \\
\text { well }\end{array}$ & (5) 2 & 30 & 4 & $650 / 273 / 4 \mathrm{~mm}$ & 4JG52-1 4JG52-4 & 0 \\
\hline & $\begin{array}{l}\text { Spare and observation } \\
\text { well }\end{array}$ & (7) & 63 & 4 & $650 / 273 / 6 \mathrm{~mm}$ & 4JG7-1 4JG7-4 & $8 \mathrm{~m}$ \\
\hline \multirow{3}{*}{ Out pit } & Observation well & (7) & 60 & 4 & $650 / 273 / 6 \mathrm{~mm}$ & 4WG7-1 4WG7-4 & $8 \mathrm{~m}$ \\
\hline & Observation well & (8) 21 & 70 & 2 & $650 / 273 / 6 \mathrm{~mm}$ & 4WG8-1 4WG8-2 & $8 \mathrm{~m}$ \\
\hline & Observation well & (8) $22 \sim 9)$ & 90 & 1 & $850 / 325 / 6 \mathrm{~mm}$ & 4WG9-1 & $8 \mathrm{~m}$ \\
\hline
\end{tabular}


Table 3 Working conditions of the influence of three-dimensional curtain on deep foundation pit dewatering

\begin{tabular}{ccccc}
\hline $\begin{array}{c}\text { Working } \\
\text { condition }\end{array}$ & $\begin{array}{c}\text { Depth of } \\
\text { vertical } \\
\text { curtain }(\mathrm{m})\end{array}$ & $\begin{array}{c}\text { Buried depth } \\
\text { of HSRB roof } \\
(\mathrm{m})\end{array}$ & $\begin{array}{c}\text { Thickness } \\
\text { of HSRB } \\
(\mathrm{m})\end{array}$ & $\begin{array}{c}\text { Hydraulic } \\
\text { conductivity of } \\
\text { HSRB }(\mathrm{cm} / \mathrm{s})\end{array}$ \\
\hline 1 & & $/$ & $/$ & $/$ \\
2 & 82 & 4 & $5 \times 10^{-3}$ \\
3 & & 84 & 4 & $5 \times 10^{-3}$ \\
4 & 86 & 4 & $5 \times 10^{-3}$ \\
5 & & 88 & 4 & $5 \times 10^{-3}$ \\
6 & & 90 & 4 & $5 \times 10^{-3}$ \\
7 & & 42 & 4 & $5 \times 10^{-3}$ \\
8 & 86 & 4 & $5 \times 10^{-3}$ \\
9 & & 82 & 4 & $5 \times 10^{-3}$ \\
10 & & 82 & 5 & $5 \times 10^{-3}$ \\
11 & & 82 & 6 & $5 \times 10^{-3}$ \\
12 & & 82 & 6 & $5 \times 10^{-3}$ \\
13 & & 82 & 6 & $1 \times 10^{-2}$ \\
14 & & 82 & 5 & $1 \times 10^{-4}$ \\
15 & & 82 & $5 \times 10^{-4}$ \\
\hline
\end{tabular}

Table 4 Combination forms of three dimensional curtain

\begin{tabular}{ccccc}
\hline Working & $\begin{array}{c}\text { Buried } \\
\text { depth of } \\
\text { condition } \\
\text { HSRB } \\
\text { roof } \\
(\mathrm{m})\end{array}$ & $\begin{array}{c}\text { Thickness of } \\
\text { HSRB }(\mathrm{m})\end{array}$ & $\begin{array}{c}\text { Hydraulic } \\
\text { conductivity } \\
(\mathrm{cm} / \mathrm{s})\end{array}$ & $\begin{array}{c}\text { The form of three- } \\
\text { dimensional } \\
\text { curtain }\end{array}$ \\
\hline 1 & $/$ & 4 & $5 \times 10^{-3}$ & $/$ \\
2 & 82 & 4 & $5 \times 10^{-3}$ & Inner-wrapped type \\
3 & 84 & 4 & $5 \times 10^{-3}$ & Transitional type \\
4 & 86 & 4 & $5 \times 10^{-3}$ & Flush type \\
5 & 88 & 4 & $5 \times 10^{-3}$ & Separated type \\
6 & 90 & 4 & $5 \times 10^{-3}$ & Separated type \\
7 & 92 & 4 & $5 \times 10^{-3}$ & Separated type \\
\hline
\end{tabular}


Table 5 Working conditions of different pumping rates

\begin{tabular}{ccccc}
\hline $\begin{array}{c}\text { Working } \\
\text { condition }\end{array}$ & $\begin{array}{c}\text { Buried depth of } \\
\text { HSRB roof }(\mathrm{m})\end{array}$ & $\begin{array}{c}\text { Thickness of } \\
\text { HSRB }(\mathrm{m})\end{array}$ & $\begin{array}{c}\text { Hydraulic } \\
\text { conductivity of } \\
\text { HSRB }(\mathrm{cm} / \mathrm{s})\end{array}$ & $\begin{array}{c}\text { Pumping rates } \\
\left(\mathrm{m}^{3} / \mathrm{d}\right)\end{array}$ \\
\hline 2 & 82 & 4 & $5 \times 10^{-3}$ & 2950 \\
8 & 82 & 4 & $5 \times 10^{-3}$ & 2500 \\
9 & 82 & 4 & $5 \times 10^{-3}$ & 2000 \\
\hline
\end{tabular}

Table 6 Working conditions of different HSRB thicknesses

\begin{tabular}{ccccc}
\hline $\begin{array}{c}\text { Working } \\
\text { condition }\end{array}$ & $\begin{array}{c}\text { Buried depth of } \\
\text { HSRB roof } \\
(\mathrm{m})\end{array}$ & $\begin{array}{c}\text { Thickness of } \\
\text { HSRB }(\mathrm{m})\end{array}$ & $\begin{array}{c}\text { Hydraulic } \\
\text { conductivity } \\
\text { of HSRB } \\
(\mathrm{cm} / \mathrm{s})\end{array}$ & $\begin{array}{c}\text { Pumping rates } \\
\left(\mathrm{m}^{3} / \mathrm{d}\right)\end{array}$ \\
\hline 8 & 82 & 4 & $5 \times 10^{-3}$ & 2500 \\
10 & 82 & 3 & $5 \times 10^{-3}$ & 2500 \\
11 & 82 & 5 & $5 \times 10^{-3}$ & 2500 \\
12 & 82 & 6 & $5 \times 10^{-3}$ & 2500 \\
\hline
\end{tabular}

Table 7 Working conditions of HSRB with different hydraulic conductivities

\begin{tabular}{ccccc}
\hline $\begin{array}{c}\text { Working } \\
\text { condition }\end{array}$ & $\begin{array}{c}\text { Buried depth } \\
\text { of HSRB roof } \\
(\mathrm{m})\end{array}$ & $\begin{array}{c}\text { Thickness of } \\
\text { HSRB } \\
(\mathrm{m})\end{array}$ & $\begin{array}{c}\text { Hydraulic } \\
\text { conductivity } \\
\text { of HSRB } \\
(\mathrm{cm} / \mathrm{s})\end{array}$ & $\begin{array}{c}\text { Pumping } \\
\text { rates } \\
\left(\mathrm{m}^{3} / \mathrm{d}\right)\end{array}$ \\
\hline 13 & 82 & 6 & $1 \times 10^{-2}$ & 2500 \\
12 & 82 & 6 & $5 \times 10^{-3}$ & 2500 \\
14 & 82 & 6 & $1 \times 10^{-3}$ & 2500 \\
15 & 82 & 6 & $5 \times 10^{-4}$ & 2500 \\
\hline
\end{tabular}

